\title{
Transfection types, methods, and strategies: A technical review
}

\author{
Zhi Xiong Chong ${ }^{1}$, Swee Keong Yeap ${ }^{2}$, Wan Yong Ho ${ }^{\text {Corresp. } 1}$ \\ ${ }^{1}$ School of Pharmacy, University of Nottingham - Malaysia Campus, Semenyih, Selangor, Malaysia \\ ${ }^{2}$ China-ASEAN College of Marine Sciences, Xiamen University Malaysia, Sepang, Selangor, Malaysia \\ Corresponding Author: Wan Yong Ho \\ Email address: WanYong.Ho@nottingham.edu.my
}

Transfection is a modern and powerful method used to insert foreign nucleic acids into eukaryotic cells. The ability to modify host cells' genetic content enables the broad application of this process in studying normal cellular processes, disease molecular mechanism, and gene therapeutic effect. In this review, we summarized and compared the findings from various reported literature on the characteristics, strengths, and limitations of various transfection methods, type of transfected nucleic acids, transfection controls, and approaches to assess transfection efficiency. With the vast choices of approaches available, we hope that this review will help researchers, especially those new to the field, in their decision making over the transfection protocol or strategy appropriate for their experimental aims. 


\title{
1 Transfection types, methods, and strategies: A technical review
}

Zhi Xiong Chong ${ }^{1}$, Swee Keong Yeap ${ }^{2}$, and Wan Yong Ho ${ }^{1 *}$

\author{
aSchool of Pharmacy, University of Nottingham - Malaysia Campus, Semenyih, Selangor, \\ Malaysia; khyy5czx@nottingham.edu.my, WanYong.Ho@nottingham.edu.my \\ ${ }^{b}$ China-ASEAN College of Marine Sciences, Xiamen University Malaysia, Sepang, Selangor, \\ Malaysia; skyeap@xmu.edu.my \\ *correspondence: Wan Yong Ho, WanYong.Ho@nottingham.edu.my
}

Keywords: Transfection, methods, nucleic acids, controls, efficiency, chemicals

\begin{abstract}
Transfection is a modern and powerful method used to deliver foreign nucleic acids into eukaryotic cells. The ability to modify host cells' genetic content enables the broad application of this process in studying normal cellular processes, disease molecular mechanism, and gene therapeutic effect. In this review, we summarized and compared the findings from various reported literature on the characteristics, strengths, and limitations of various transfection methods, type of transfected nucleic acids, transfection controls, and approaches to assess transfection efficiency. With the vast choices of approaches available, we hope that this review will help researchers, especially those new to the field, in their decision making over the transfection protocol or strategy appropriate for their experimental aims.
\end{abstract}

\section{Introduction}

Transfection is a process by which foreign nucleic acids are delivered into a eukaryotic cell to modify the host cell's genetic makeup (Kim and Eberwine 2010; Chow et al. 2016). For the past 30 years, transfection has gained increasing popularity due to its wide application for studying cellular processes and molecular mechanisms of diseases (Arnold et al. 2006; Ishida and Selaru 2012; Chow et al. 2016). Understanding the molecular pathway of disease allows the discovery of specific biomarkers that may be applied to diagnose and prognose diseases (Ye et al. 2017; Roser 
31 et al. 2018). Besides, transfection can be employed as one of the strategies in gene therapy to treat 32 incurable, inherited genetic diseases (Yao et al. 2008; Yamano et al. 2010; Tomizawa et al. 2013).

33 Today, the advancement in life-sciences technology allows different types of nucleic acids to be 34 transfected into mammalian cells, and these include DNAs, RNAs as well as small, non-coding 35 RNAs such as siRNA, shRNA, and miRNA (Borawski et al. 2007; Yamano et al. 2010; Sork et al. 2016; Shi et al. 2018).

37 Generally, transfection can be classified into two types, namely stable and transient transfection (Kim and Eberwine 2010; Stepanenko and Heng 2017). Stable transfection refers to sustaining long-term expression of a transgene by integrating foreign DNA into the host nuclear genome or maintaining an episomal vector in the host nucleus as an extra-chromosomal element (Lufino et al. 2008). The transgene may then be constitutively expressed even with the replication of cells. (Recillas-Targa 2006; Kim and Eberwine 2010).

In contrast, transient transfection does not require integrating nucleic acids into the host cell genome (Riedl et al. 2018). Nucleic acids may be transfected in the form of a plasmid (Nejepinska et al. 2012) or as oligonucleotides (Igoucheva et al. 2006). Therefore, transgene expression will eventually be lost as host cells replicate (Recillas-Targa 2006; Kim and Eberwine 2010). Transient transfection is usually applied in short-term studies to investigate the effects of knock-in/-down of a particular gene (Kim and Eberwine 2010). In contrast, stable transfection is useful in long-term genetic and pharmacology studies in which large-scale protein production is needed (Elgundi et al. 2017).

A vector construct that carries the specific nucleic acids to be transfected can be further divided into either viral or plasmid vector. Viruses and plasmids facilitate the expression of a foreign transgene via the presence of a suitable eukaryotic promoter (Colosimo et al. 2000). A viral vector may trigger an immunogenic response in the host cell while a non-viral vector is comparatively less immunogenic (Hardee et al. 2017). A delivery mechanism is needed to facilitate the transfer of targeted nucleic acids or vector construct into the host cell (Kim and Eberwine 2010). Some of these entail physical methods while others involve the use of a delivery vehicle, which may be lipid-based (Balazs and Godbey 2011) or non-lipid based (Jin et al. 2014), to help enhance the contact between vector-vehicle complex with the host cell membrane, thereby facilitating the entrance of the complex into cells (Balazs and Godbey 2011). 
61 Designing and initiating a transfection assay can be challenging, especially with the vast variety 62 of transfection approaches or strategies to choose from (Gharaati-Far et al. 2018; Shi et al. 2018; Tan et al. 2019). Thus, we aimed to provide a systematic comparison between different strategies, targets, controls, reagents, and validation involved in transfection to provide an overview for beginners in this field. This review included an overview of different transfection methods (viral vs. non-viral approaches) and the common types of transfected nucleic acids (DNA, RNA, and small RNAs). Other important aspects such as the type and importance of controls, choice of methods for assessing transfection efficiency, and potential factors influencing efficiency were also discussed.

\section{Survey methodology}

A systematic literature search based on PRISMA guidelines (Moher et al. 2009) was established to identify relevant published studies or protocols that fit into this review's scope (Figure 1). Databases that were employed for the literature search included Scopus, Google Scholar, and PubMed. The keywords being used during the search included "transfection", "co-transfection", “chemicals”, "reagents", "DNA”, “siRNA”, "shRNA”, “miRNA”, “plasmid”, "oligonucleotides”, "efficiency", "safety", "cytotoxicity", "controls" and other related key terms. An initial search returned about 5000 articles, published protocols, or handbooks from various databases that reported the descriptions or comparisons between different transfection methods, types of transfected nucleic acids, transfection control, transfection efficiency assessment methods, and transfection reagents. Two independent reviewers performed article screening and the selection to avoid selective bias. About 500 articles were retained after the first screening to remove duplicated sources or articles that appeared in more than one database. Inclusion criteria of the literature selection include English articles published in the past 30 years and articles or sources that reported the description or comparison of the different transfection methods/ protocols/ strategies/ procedures. About 100 written sources that did not fit the inclusion criteria were removed, and these included letters to the editor, conference paper, and articles with inaccessible full-texts. Around 150 relevant and related published literature or handbooks were selected in the final stage to compare different transfection protocols, types of transfected nucleic acids, transfection 
91 controls, methods to assess transfection efficiencies, and transfection reagents in terms of their 92 strengths, effectiveness, safety level and limitations.

93

94 1. Transfection approaches

95 Transfection methods can be generally divided into viral, non-viral, or a combination of both 96 (hybrid) (Figure 2).

97

98

\subsection{Viral transfection}

Viral-based transfection, or more specifically known as transduction, involves using a viral vector to carry a specific nucleic acid sequence into a host cell. Retroviruses, such as lentiviruses are often used for stable transfection (Pfeifer and Verma 2001; Kim and Eberwine 2010; Fakhiri et al. 2019). In contrast, adenovirus, adeno-associated virus (AAV) and herpes virus are viral vectors which do not guarantee stable transfection (Lee et al. 2017). As compared to non-viral transfection, viral transduction is widely recognized as a highly effective method to transfect difficult-totransfect cells such as primary cells (Mali 2013; Wang et al. 2015). Generally, retroviruses can only be used to transfect dividing cells while adenoviruses, AAVs and herpes viruses can be used to transfect both dividing and non-dividing cells (Lee et al. 2017). However, viral transduction is associated with higher cytotoxicity and may pose a risk for viral infection (Kim and Eberwine 2010; Mali 2013).

A viral vector usually contains a viral envelope that surrounds and protects the virus. Surface proteins may be present on the surface of certain types of viruses, such as adenovirus, to facilitate contact and communication with the host cell (Maginnis 2018). Viral genetic materials are enclosed in a capsid, which will be unpacked upon entering the host cell. Unlike the genomes of adenoviruses, AAVs and herpes viruses which are maintained episomally (Hardee et al. 2017; Lee et al. 2017), a retroviral genome is integrated into the host genome (Lee et al. 2017). Generally, adenoviruses and herpes viruses carry double-stranded DNAs, AAVs carry single-stranded DNAs, while retroviruses carry RNAs (Lee et al. 2017). Integrase is a type of enzyme produced by viruses such as retroviruses that facilitate the integration of foreign genetic materials into the host genome (Hindmarsh and Leis 1999; Tzlil et al. 2003). In retroviruses, RNAs will be reverse transcribed into a double-stranded viral DNA before being integrated into the host cell genome for replication 
120 and expression (Hindmarsh and Leis 1999). Even in non-retroviruses that lack integrase, such as

121 the adenoviruses, integrase may be expressed through genetic engineering technique (Mogler and

122 Kamrud 2015).

123 Retroviruses that stably express transgene exhibit lower potential in triggering inflammation than

124 adenoviruses and herpes viruses that usually produce transient transgene expression but 125 inflammation in the host cell (Lee et al. 2017). However, using retroviruses for transfection is 126 associated with a high risk of insertional mutagenesis and gene disruption (Hardee et al. 2017). In 127 contrast, viruses that do not induce stable genome integration have a lower but existent risk of 128 triggering mutagenesis (Fernández-frías et al. 2020).

129 Compared to adenoviruses, AAVs exert lower immunogenicity and pathogenicity in human, which makes them a safer virus for gene therapy (Nayerossadat et al. 2012). However, the small packaging capacity $(<5 \mathrm{~kb})$ of AAVs limits their applications to deliver large-sized therapeutic genes (Lee et al. 2017). On the other hand, adenoviruses have higher packaging capacities than AAVs and were reported to be able to transduce most cell types (Lee et al. 2017). Among the several commonly used viruses for transduction, herpes viruses are found to have the largest packaging capacity ( 150kb) (Lee et al. 2017; Fernández-frías et al. 2020). Besides, herpes virus is said to have strong tropism for neuronal cells and thus, herpes virus has great potential to be employed to deliver specific nucleic acid in treating diseases of the nervous system (Lee et al. 138 2017).

\subsection{Non-viral transfection}

\subsubsection{Physical/mechanical transfection}

Non-viral based transfection approach can be further classified into a physical/mechanical method and chemical method. Commonly used physical/mechanical transfection method includes electroporation, sonoporation, magnetofection, gene microinjection, and laser irradiation (Du et al. 2018; Hamann et al. 2019; Meng et al. 2019). Electroporation is a commonly used physical transfection method that uses electrical voltage to transiently increase the cell membrane permeability to allow the entry of the foreign nucleic acid (Prasanna and Panda 1997). This method is commonly employed to transfect difficult-to-transfect cells such as primary cells, stem cells and B cell lines (Jordan et al. 2008; Stroh et al. 2010; Liew et al. 2013; Canoy et al. 2020). However, 
150 the use of high voltage may cause cell necrosis, apoptosis, and permanent cell damage (Piñero et 151 al. 1997; Kim and Eberwine 2010; Mali 2013). Ultrasound-assisted transfection or sonoporation 152 involves the use of microbubbles technique to create holes on the cell membrane to ease the 153 transfer of genetic materials (Meng et al. 2019), while laser irradiation-assisted transfection uses 154 a laser beam to create small holes on the plasma membrane to allow entry of foreign genetic 155 substances (Pylaev et al. 2019). Like electroporation, both sonoporation and laser-assisted

156

157

158

159

160

161

162

163

164

165

166

167

168

169

170

171

172

173

174

175

176

177

178

179

180 transfection also pose risks of damaging the cell membrane and irreversible cell death (Kim and Eberwine 2010; Mali 2013). Comparatively, magnet-assisted transfection, or magnetofection that uses magnetic force to aid in the transfer of foreign genetic materials, appears to be less destructive to the host cell despite its low efficiency (Wang et al. 2015). Gene microinjection, on the other hand, involves the use of a specific needle to puncture the cell to inject the desired nucleic acids into the nucleus of the host cell (Chow et al. 2016). However, this technique necessitates specially trained personnel or robotic system that can perform the procedure with high precision to prevent cell damage (Kim and Eberwine 2010; Chow et al. 2016) and is thereby of great value in clinical applications such as gene therapy (Nikol et al. 1999). Compared to physical or mechanical transfection methods, chemical transfection involves using specially designed chemicals or compounds to aid in transferring the foreign nuclei acid into the host cells (Hamann et al. 2019; Tan et al. 2019).

\subsubsection{Chemical transfection}

Chemical transfection can be categorized into liposomal-based or non-liposomal-based (Kim and Eberwine 2010). Examples of the commercially available chemical transfection reagents are summarized in Figure 3. Liposomal-based transfection reagent is a chemical that enables the formation of positively charged lipid aggregates that could merge smoothly with the phospholipid bilayer of the host cell to allow the entry of the foreign genetic materials with minimal resistance (Kim and Eberwine 2010; Mali 2013).

On the other hand, non-liposomal transfection reagents can be further divided into several classes, including calcium phosphate, dendrimers, polymers, nanoparticles, and non-liposomal lipids (Kim and Eberwine 2010; Mali 2013; Valetti et al. 2013). Calcium phosphate is one of the cheapest chemicals used in transfection that involves binding the positively charged calcium ions $\left(\mathrm{Ca}^{2+}\right)$ with the negatively charged nucleic acids to form a precipitate before being taken up by host cell 
181 (Guo et al. 2017). However, the success rate of calcium phosphate transfection is comparatively 182 low and requires prior optimization to achieve high transfection efficiency (Guo et al. 2017). 183 Dendrimers are 3-dimensional, highly branched organic macromolecules that could form 184 complexes with nucleic acids claimed to be superior to calcium phosphate as an alternative non185 liposomal transfection reagent (Dufès et al. 2005). However, transfection efficiency using 186 dendrimers is still lower than viral vectors and liposomal reagents (Dufès et al. 2005; Borawski et 187 al. 2007). Cationic polymers could also form complexes with the negatively charged nucleic acids, 188 which aid in the uptake of the genetic materials by cells through endocytosis (Kim and Eberwine 189 2010; Mali 2013). Compared to viral vectors and lipofection, cationic polymers produce less cytotoxicity but are also compromised with lower efficiency (Kim and Eberwine 2010; Mali 2013). Recently, nanoparticles are emerging as an alternative option in non-liposomal transfection due to their small size, which enhances the entry of nucleic acids into the host cell (Sandhu et al. 2002). Nanoparticles were reported to cause little cytotoxicity to the transfected cells, but more studies may be necessary to carefully assess its efficiency and long-term safety in clinical applications (Al-Dosari and Gao 2009). Non-liposomal lipid-based nanocarrier is a type of lipid-formulated nanocarrier that allows fast and effective delivery of nucleic acids into eukaryotic cells (Valetti et al. 2013). Compared to liposomal lipid nanocarriers, this nanocarrier was claimed to be safer, but its preparation is tedious and expensive (Valetti et al. 2013; Meisel and Gokel 2016).

\subsection{Hybrid of viral and non-viral transfection methods}

The combination of viral and non-viral transfection method is known as a hybrid approach, and the use of such a combined method was reported to produce higher transfection efficiency compared to other transfection methods such as using polyplexes alone (Pinnapireddy et al. 2019). However, a hybrid method appears to be more laborious and costly due to the need for the artificial synthesis of the unique viral-like vectors linked with other chemicals such as glucose (Pinnapireddy et al. 2019) and lipids (Keswani et al. 2013). Nevertheless, the hybrid-based transfection approach was also proven to be safe and able to produce stable human cell lines that constantly expressed the proteins of interest (Keswani et al. 2013; Pinnapireddy et al. 2019). 
211

212

213

214

215

216

217

218

219

220

221

222

223

224

225

226

227

228

229

230

231

232

233

234

235

236

237

238

239

\subsection{Deoxyribonucleic acids (DNA)}

In transfection, DNAs are normally transported into a host cell via a viral or non-viral vector such as plasmid (Balak et al. 2019; Pang et al. 2019). The plasmid's basic structure includes a promoter, origin of replication, multiple cloning site, gene of interest, and selection marker (Nora et al. 2018).

The origin of replication is needed for plasmid replication, while the multiple cloning site contains unique restriction enzyme cut sites for insertion of foreign genes (Nora et al. 2018). The presence of appropriate eukaryotic promoters such as CMV or EF-1 $\alpha$ allows the expression of a foreign gene in the host cell (Wang, $\mathrm{Xu}$, et al. 2017). Plasmid DNA may be transfected in the form of linear and supercoiled DNA (Mitchenall et al. 2018). Transfection using supercoiled plasmid DNA will generally produce higher efficiency as compared to linear DNA, which is more susceptible to degradation by exonucleases (Groll et al. 2006). Linearized DNA, however, is more recombinogenic and can thus be more readily integrated into the host genome to achieve stable transfection (Groll et al. 2006; Hardee et al. 2017).

The use of a plasmid vector does not guarantee constitutive transgene expression nor stable foreign DNA integration into the host genome (Delrue et al. 2018). In other words, as cells divide, a foreign gene will not be constitutively expressed and eventually lost if it has not been integrated into the host cell's genome (Mali 2013). Therefore, using an appropriate selection marker such as an antibiotic resistance gene or fluorescence protein co-expressed with the transgene is necessary to select and maintain stably transfected cells in culture (Kaufman et al. 2008). Like plasmid vector transfection, the introduction of a selection marker gene into a viral vector is also useful for selecting stably transduced cells (Tomás et al. 2018).

In comparison to viral DNA transfection, plasmid-based DNA transfection is less immunogenic without the risk of viral integration into the host cell genome (Mali 2013). However, the transfection efficiency and protein production of plasmid-based DNA transfection is comparatively lower (Oh and Kessler 2018).

\subsection{Ribonucleic acid (RNA) and messenger RNA (mRNA)}

Similar to DNA transfection, RNA may be introduced into eukaryotic cells via RNA-based viral or non-viral vectors (Mogler and Kamrud 2015; Oh and Kessler 2018; Ylosmaki et al. 2019). In 
240 comparison to transfection involving DNAs, RNA transfection might produce higher transfection

241 efficiency as the latter does not require transit across the nuclear membrane (Zou et al. 2010).

242 Without the need for genome integration, transcription, and post-transcriptional processing, RNA

243 transfection may also accelerate the desired protein (Oh and Kessler 2018; Ylosmaki et al. 2019).

244 The use of mRNA-based vectors may also prevent complications due to integration into the host

245 genome, thereby allowing specific, desired proteins to be expressed (Mogler and Kamrud 2015;

246 Oh and Kessler 2018). However, protein expression is transient following RNA transfection, and

247 RNAs are comparatively less stable than DNAs, making them more prone to degradation when

248 transported intracellularly (Mogler and Kamrud 2015; Nowakowski et al. 2017; Oh and Kessler 249 2018).

250

251

252

253

254

255

256

257

258

259

260

261

262

263

264

265

266

267

268

\subsection{Common and special oligonucleotides (small ribonucleic acids)}

Small RNAs are RNA molecules of 18-200 base pairs (bp) in length and possess the ability to regulate post-transcriptional gene regulation and RNA modification (Watson et al. 2019). Examples of small RNAs include microRNAs (miRNAs), small interfering RNAs (siRNAs), short hairpin RNAs (shRNAs), and piwi-interacting RNA (piRNA) (Watson et al. 2019).

miRNAs and piRNAs are both endogenous and single-stranded small RNAs. miRNAs (18-25bp) are involved in post-transcriptional regulation of downstream mRNAs by inhibiting the targeted mRNA or interfering with its translation initiation (Wilczynska and Bushell 2015). On the other hand, piRNAs (24-30bp) take part in transposon silencing and post-transcriptional regulation (Chuma and Nakano 2013). Similar to miRNAs and piRNAs, siRNAs also play a role in regulating post-transcriptional gene expression (Allison and Milner 2014). siRNAs are normally 20-24bp in length, which may be expressed as endogenous or exogenous double-stranded small RNAs (Allison and Milner 2014). shRNA is a type of endogenous, double-stranded small RNA with a hairpin loop (Mcintyre et al. 2011). shRNA may bind to the complementary sequence on an mRNA to degrade it (Mcintyre et al. 2011).

One should determine its experimental need before deciding on the appropriate small RNA molecule for transfection-related functional assay. For instance, siRNA is highly specific to only one target, whereas miRNA has the potential to regulate multiple downstream targets (Lam et al. 2015). 
269 Today, various types of short-length oligonucleotides (Table 1) may be artificially synthesized to

270 imitate the small RNA molecules for functional studies of the knock-in/-down/-out effects of these

271 small RNA molecules. The commonly used oligonucleotides can be grouped into either mimic or

272 antagonist (Bell and Micklefield 2009). A mimic is a small RNA-based oligonucleotide (may be

273 piRNA, miRNA, or siRNA) that has a structure which enables it to bind to a targeted mRNA to

274 inhibit its function, resulting in translational repression of a specific gene (Fu et al. 2014;

275 Ahmadzada et al. 2018; Edvard Smith and Zain 2019). In contrast, an antagonist is an

276 oligonucleotide that will bind to the complementary small RNA strand such as miRNA to

277 antagonize its activity, thereby increasing the targeted gene expression (Edvard Smith and Zain

278 2019; Fu et al. 2019).

279 With the advancement in the oligonucleotide biosynthesis industry, different types of modified

280 oligonucleotides were also introduced into the market to increase the efficiency of transfecting

281 small RNA oligonucleotides. One of them is the agomirs and antagomirs that are chemically

282 modified to improve their binding affinities to target and block exonuclease activities (Merhautova

283 et al. 2016; Hu et al. 2017). An agomir is an artificially modified double-stranded miRNA mimic

284 designed to exert higher target repression activity than conventional miRNA mimics (Krützfeldt

285 et al. 2005; Fu et al. 2019). On the other hand, antagomir is a specially designed single-stranded

286 miRNA analog that aims to inhibit a specific miRNA (Krützfeldt et al. 2005; Fu et al. 2019). Both

287 agomir and antagomir were claimed to be more stable, effective, specific, and have higher binding

288 affinity to the host cell membrane than the normal mimics or antagonists (Krützfeldt et al. 2005;

289 Chen et al. 2015; Hu et al. 2017).

290 Locked nucleic acids (LNA) is another type of modified oligonucleotide that possesses an extra 291 methylene bridge in at least one of its nucleotides to enhance the stability of its ribose ring structure 292 (Grünweller and Hartmann 2007). Its locked ribose structure makes LNA shorter than the 293 commonly used oligonucleotides, thereby enabling it to show higher efficiency, stability, and 294 binding affinity than traditional oligonucleotides (Tolstrup et al. 2003; Chan et al. 2005; Fabani 295 and Gait 2008; Qiagen miRCURY LNA Mimics and Inhibitors and Target Site Blockers 296 Handbook 2017). The application of LNA-based oligonucleotides has been reported in various 297 biochemical or functional assays that involved the deliveries of small RNA molecules such as 298 siRNA (Elmén et al. 2005), miRNA (Roberts et al. 2006), and piRNA (Lee et al. 2011). Some 
299

300

301

302

303

304

305

306

307

308

309

310

311

312

313

314

315

316

317

318

319

320

321

322

323

324

325

326

LNA-based transfection requires no transfection reagent (Hillebrand et al. 2019), which could minimize secondary effects from the reagents during transfection.

\subsection{Combination of different transfected nucleic acids or co-transfection}

Co-transfection is a process in which more than one type of nucleic acid is being introduced into the eukaryotic cell (Figure 4) (Hannig and Jany 2013; Li et al. 2014; Russell et al. 2015). Some examples of the combinations include multiple plasmid DNAs (Karda et al. 2019; Bauler et al. 2020), siRNA and plasmid DNA (Kwak et al. 2019; Setten et al. 2019), and multiple miRNAs into the same cell (Seo et al. 2015; Tsukita et al. 2017).

Generally, multiple plasmid DNA co-transfection aims to introduce more than one type of foreign genes into the host cells. One of its applications is to produce synthetic viral or hybrid vectors that consist of several plasmid DNA components (Karda et al. 2019; Bauler et al. 2020). An example is the generation of a lentivirus from several plasmid vectors such as transfer, envelope, and packaging vectors in HEK293 cell line (Merten et al. 2016). Besides, co-transfection of multiple plasmid DNAs can also be applied in protein-protein interaction (PPI) studies to investigate the relationships between one protein to another (Deriziotis et al. 2014; Vyncke et al. 2019). PPIs can be assessed using physical measurement based on energy transfer from one donor protein to a recipient protein (Deriziotis et al. 2014) or via chemical measurement in which the interactive activity between an expressed protein with another protein can be detected via an appropriate reporting system upon stimulation (Vyncke et al. 2019). The latter luciferase-based method is known as bioluminescence resonance energy transfer (BRET), and it serves as an alternative method to fluorescence resonance energy transfer (FRET) in studying PPIs (Khamlichi et al. 2019). Co-transfection of multiple plasmids can also be applied in transfection which involves the delivery of plasmids that encode Cas9 protein and guide RNA to the host cell for genome editing using the CRISPR/Cas9 genome engineering system (Gam et al. 2019). Apart from using multiple plasmids, a bicistronic vector, a vector capable of expressing two different genes joined using an internal ribosome entry site (IRES) with only one promoter, is another way to deliver different genes to a host cell (Li and Wang 2012). 
327 Co-transfection of small RNA and plasmid DNA can be used to assess transfection efficiency

328 (Horibe et al. 2014). This is feasible by introducing a plasmid containing a luciferase reporter gene 329 in which its 3' UTR can be recognized by a specific small RNA such as miRNA, which then allows 330 binding by the small RNA to inhibit luciferase expression (Repele and Manu 2019). On the other 331 hand, co-transfection of small RNA and plasmid DNA is also essential in RNA interference 332 (RNAi) study to determine the regulatory effects of a specific small RNA such as siRNA on the specific gene expression in a host cell (Keller et al. 2018; Ervin et al. 2019). Small, non-coding RNAs such as siRNAs are well known for their epigenetic regulation capabilities or, more specifically, regulation of specific gene expression post-transcriptionally (Zhao and Zhang 2018). siRNA mimics and a plasmid DNA carrying the specific gene linked to a luciferase reporting system can be simultaneously co-transfected into a target cell (Salim et al. 2020). Successful knockdown of specific gene expression by the siRNA mimic will lead to a measurable decrease in luciferase activity (Peralta-Zaragoza et al. 2016; Shyamasundar et al. 2016).

Co-transfection may also involve different small molecules such as miRNAs, which is useful in studying the effects of small RNAs on the targeted host cells (Tsukita et al. 2017). For instance, if the introduction of a miRNA mimic can affect the expression of a specific downstream gene in a particular cell type, it is then expected that simultaneous transfection of its inhibitor sequence into the same cell would reduce the post-transcriptional regulatory effect exerted by the miRNA mimics sequence alone (Seo et al. 2015).

As compared to transfection of a single nucleic acid type, co-transfection, which involves the transfer of multiple nucleic acids into the same cell, is generally more challenging as not all nucleic acids types can be effectively transferred, and this may depend on the transfection method and cell type involved (Kretzmann et al. 2018).

350

351

352

353

354

355 356

\section{Transfection controls}

The use of control in a transfection experiment is vital for determining the effect and efficiency of transfection reagents and nucleic acids used (Godbey et al. 2008; Yang et al. 2011; Jin et al. 2015; Ayub et al. 2016).

Generally, both plasmid transfection and oligonucleotide transfection experiments require a positive control, a negative control, an un-transfected control, and a mock transfection control 
357 (Yang et al. 2011; Jin et al. 2015; Ayub et al. 2016; Stepanenko and Heng 2017; Gharaati-Far et 358 al. 2018). A positive control is a DNA or RNA that had previously been proven to cause known 359 effects to the transfection experiment, such as affecting the expression of a specific downstream 360 genetic target (Ayub et al. 2016). A positive control is needed during the initial stage of a 361 transfection work to establish an optimized transfection protocol, and afterward, the positive 362 control can act as a reference to be compared to the experimental group. On the other hand, a 363 negative control is used to confirm if an intended gene expression change in the host cell is 364 attributable to the transfection instead of other causes. In plasmid DNA transfection, a negative 365 control can be a reaction that lacks the DNA, the transfection delivery vehicle, or absence of both with only the host cell (Liang, Knight, et al. 2013). In small RNA transfection, a negative control contains a non-homology sequence, which is usually a scrambled sequence that shares the same nucleotide length and composition as the target sequence but not homologous to any known mammalian gene (Yang et al. 2011; Ayub et al. 2016).

An un-transfected control involves the culture of cells without transfection reagents and nucleic acids, which act as a control for basal information about the host cell, including viability, phenotype, and more importantly, the baseline expression level of target gene without the impact from transfection (Godbey et al. 2008; Gharaati-Far et al. 2018). Mock transfection refers to transfection without the genetic target or nucleic acids, which allows the assessment of effects resulting from transfection reagents such as background auto-fluorescence noise (Hunt et al. 2010; Gharaati-Far et al. 2018). In plasmid transfection experiments, the use of an empty plasmid control, which contains only the vector backbone with the exclusion of the transgene, is recommended as the mock transfection control (Jin et al. 2015; Kamens 2015).

\section{Assessing transfection efficiency}

Assessing the efficiency of transfection is vital, especially in functional studies which require high transfection efficiencies to warrant post-transcriptional regulation of specific downstream targets (Weilin et al. 2004; Marjanovič et al. 2014; Peng et al. 2017). A variety of strategies may be cons (Table 2). 
387 Real-time polymerase chain reaction (qPCR) is a quantitative approach for assessing transfection 388 efficiency via direct measurement of the expression level of specific foreign nucleic acids in the 389 cell or other intracellular nucleic acids that could be affected by exogenous nucleic acids such as 390 miRNAs (Godbey et al. 2008; Jiwaji et al. 2010; Thomson et al. 2013). In the case of transient transfection, qPCR should be performed after each transfection to ensure good transfection 392 efficiency before proceeding to downstream experiments (Thomson et al. 2013).

393

394

395

Co-transfection with plasmid reporter system is another strategy that can be used to assess transfection efficiency by expressing specific reporter proteins such as luciferase or $\beta$ galactosidase (Nasim and Trembath 2005; Jiwaji et al. 2010; Yamano et al. 2010; Horibe et al. 2014). Taking luciferase reporter system in small RNA interference (RNAi) study as an example, successful transfection of miRNA is indicated by downregulation of luciferase activity, which is due to mRNA degradation as a result of the binding of miRNA to the 3 '-end of the transcribed luciferase mRNA (Aldred et al. 2011).

Fluorescence microscopy is another common, easy, and rapid method to assess transfection efficiency (Marjanovič et al. 2014; Peng et al. 2017). It usually involves using a vector that carries a fluorescence reporting gene or oligonucleotides tagged with fluorophores to allow fluorescence detection (Faltin et al. 2013). However, fluorescence microscopy provides only qualitative or semi-quantitative measurement of transfected efficiency, which can be determined using specialized software such as ImageJ (Jensen 2013). In contrast, flow cytometry allows for more precise quantitation of the cells that express a specific fluorescent gene to assess transfection efficiency (Ho et al. 2006; Marjanovič et al. 2014; Homann et al. 2017).

Another way of assessing transfection efficiency is via monitoring specific protein expression post-transfection (Alabdullah et al. 2019; Mori et al. 2020). Introduction of a transgene into the cell may alter the expression of a protein encoded by the transgene or other genes in the cell (Kim and Eberwine 2010). Likewise, transfection of small RNAs may also regulate the expression of specific downstream genetic targets in the host cell (Liang, Hart, et al. 2013). Immunoblotting and immunofluorescent staining may be employed to assess changes in the expression of protein posttransfection. The use of specific antibodies for binding to targeted proteins are vital in both methods, where the latter requires the use of secondary fluorescently labelled antibodies that bind to the primary antibodies to detect the protein of interest (Sograte-Idrissi et al. 2020). On the other 
417 hand, in immunoblotting, horseradish peroxidase (HRP)-conjugated secondary antibodies can be

418 used to bind to the primary antibodies for specific protein detection (Lin et al. 2016).

419 Immunoblotting allows semi-quantification of protein expression while immunofluorescence

420 staining allows detection via fluorescent microscopy or quantification via flow cytometry. The

421 assessment of transfection efficiency via examination of specific protein expression is more

422 reproducible and straightforward (Zeitelhofer et al. 2007; Homann et al. 2017). However, the issue

423 of non-specific proteins binding inherent from the use of antibodies (Liang, Mason, et al. 2013;

424 Niikura and Kitagawa 2016) and the likelihood of obtaining false-negative results, which may be

425 caused by untimely assaying of protein expression (Brunner et al. 2000) remain as the drawbacks

426 of using these methods.

427

428

429

430

431

432

433

434

435

436

437

438

439

440

441

442

443

444

445

446

447

\subsection{Factors influencing transfection efficiency}

The efficiency of chemical transfection depends greatly on a few factors such as type of reagents used, the origin and nature of target cells, and an optimum DNA to reagent ratio chosen (Supplementary Table 1) (Gharaati-Far et al. 2018; Shi et al. 2018; Wang et al. 2018). In this section, we will review past research that reported the influence of these factors on various transfection strategies' efficiency.

\subsubsection{Factors influencing the efficiency of viral transfection}

Viral vectors such as lentiviruses are useful in gene therapy due to their ability to carry large-sized nucleic acid and deliver their targets to both non-dividing and dividing cells (Karda et al. 2019). A few factors had been shown to potentially affect efficiencies of viral transduction, such as target cell types, type of promoter used, the concentration of vector, and condition of transduction medium used (Table 3) (Ikeda et al. 2002; Denning et al. 2013).

In an in vitro study that evaluated the use of human immunodeficiency virus (HIV) and equine infectious anemia virus (EIAV) for gene transduction, varying degrees of efficiencies were observed between the two viruses on different cell lines from human, hamster, cat, dog, horse, and pig. The transduction efficiency using HIV was generally better than EIAV on most cell types, while the infectivity of both viruses on rodent cells was weak (Ikeda et al. 2002). In the same study, the type of promoter was also suggested as a factor that may influence transduction 
448 efficiency whereby HIV containing the internal promoter EF-1 $\alpha$ in replacement of CMV promoter 449 exhibited higher transduction efficiency on murine and rat cells (Ikeda et al. 2002). Besides, viral 450 concentration was suggested as another factor influencing efficiency. Among a few other 451 parameters tested in the evaluation by Haas et al. (2000), namely HIV lentiviral vector construct 452 containing different accessory proteins, presence/absence of fibronectin fragment and addition of 453 polycations protamine sulfate into transduction medium on human cord blood and embryonic 454 kidney cells, only viral titer appeared to be directly associated with viral transduction efficiency.

455 On the other hand, the condition of the transfection medium may also affect transduction 456 efficiency. For instance, the use of fetal bovine serum was shown to yield better transduction 457 efficiency than bovine calf serum during transduction (Denning et al. 2013). Likewise, polycations 458 such as DEAE-dextran were shown to minimize repulsion forces between negatively-charged cells 459 and facilitated viral transduction (Denning et al. 2013).

\subsubsection{Factors influencing the efficiency of chemical transfection}

461

\subsubsection{Type of chemical transfection reagents}

463

The choice of a suitable transfection reagent can depend on several factors, including the type of 465 transfected nucleic acids and complexity of the transfection (single or co-transfection) (Attractene Transfection Reagent Handbook 2008; HiPerFect Transfection Reagent Handbook 2010; Kim and Eberwine 2010; Trans IT-X2 ® Dynamic Delivery System Protocol 2019). Some reagents such as Effectene and TransIT-X2 are specially dedicated for plasmid DNA transfection (Homann et al. 2017; Ormeño et al. 2020), while some reagents such as Lipofectamine RNAiMAX are more suited for transfection of small oligonucleotides (Jensen et al. 2014; Wang et al. 2018). Several reagents had also been suggested to be suitable for co-transfection of multiple DNA plasmids, whereas a distinct group of reagents is catered for mixed DNA/small RNA molecules cotransfection (Supplementary Table 1) (Duportet et al. 2014; Kretzmann et al. 2018; Shi et al. 2018; Wang et al. 2018; Tan et al. 2019).

475

\subsubsection{Type of chemical transfection reagents}

477

478

\section{Primary and stem cells}


480 Primary mammalian cells are generally less susceptible to transfection than other cell types due to 481 its finite lifespan and limited expansion capacity (Oh et al. 2007; Yamamoto et al. 2017; 482 Alabdullah et al. 2019). Non-liposomal-based reagents were shown to be superior than liposomal 483 reagents in transfecting primary human cells, including PEC (Young et al. 2002), HASMC and 484 HAEC (Kiefer et al. 2004), primary human myoblast (Arnold et al. 2006), and AGS (Gharaati-Far 485 et al. 2018). In contrast, liposomal-based reagents such as Lipofectamine and DharmaFECT 486 families were reported to produce higher transfection efficiencies than non-liposomal reagents in 487 transfecting other primary human cells such as the primary umbilical cord vein endothelial cells 488 (HUVEC) (Hunt et al. 2010) and BM-MSC (Cheung et al. 2018).

489

490

491

492

493

494

495

496

497

498

499

500

501

502

503

504

505

506

507

508

In a study that involved transfection of plasmid DNA into HUVEC, the use of non-liposomal reagents including Effectene and FuGENE 6 produced better transfection efficiency (34\% and $33 \%$ ) than the liposomal reagent DOTAP (18\%) (Young et al. 2002). In another study that transfected HUVECs with plasmid DNA (Hunt et al. 2010), liposomal-based reagents, however, demonstrated higher transfection efficiencies ( $\sim 38 \%$ at 48 hours for Lipofectamine LTX and $\sim 23 \%$ at 48 hours for Lipofectamine 2000) as compared to non-liposomal reagents such as Effectene and FuGENE 6 or HD (all $<20 \%$ at 48 hours). Lipofectamine LTX and Lipofectamine 2000 were reported to show similar cytotoxic effects to HUVEC but the cytotoxic effects of other reagents were not reported. The efficiencies of liposomal-based vs. non-liposomal-based reagents in transfecting HUVECs could not be concluded in these studies, mainly due to differences in the range of reagents used. However, consistent observations that transfection efficiencies remained below $40 \%$ regardless of the reagents used had undoubtedly implicated primary cells as a hard-totransfect cell type.

Human primary stem cells is another well recognized hard-to-transfect cell type, where poor efficiency and low cell viability remain as the greatest challenge in transfecting this cell type (Ervin et al. 2019; Tan et al. 2019). In 2015, Wang et al. (2015) reported that transfection reagents such as Lipofectamine 2000 and XtremeGENE HP produced very poor transfection efficiencies $(<6 \%)$ in human periodontal ligament stem cell as compared to the positive control lentiviral vector that achieved $\sim 95 \%$ of transfection efficiency. Compared to the magnetic assisted transfection technique employed in the same study, the latter showed greater transfection efficiency $(\sim 11 \%)$ 
509 with lower toxicity. In another study that involved human bone marrow mesenchymal stem cell

510 (hBM-MSC), Lipofectamine LTX was shown to produce the best transfection efficiency (at least 511 three times higher) than other reagents such as TransIT-2020, Lipofectamine 3000, and 512 polyethylenimine (PEI) but presented low cell viability (<50\%) (Cheung et al. 2018).

513 Comparatively, a better outcome may be attained by using TransIT-2020 reagent that was shown 514 to achieve around $30 \%$ efficiency, with recovery up to $90 \%$ of the cells and attainment of about 515 95\% of cell stemness (Cheung et al. 2018). Another example of hard-to-transfect stem cell is 516 induced pluripotent stem cells (iPSCs). In a study which compared different non-viral methods for 517 transfecting human iPSC-derived cardiomyocytes (hiPSC-CMSs), Lipofectamine STEM was 518 shown to produce superior transfection efficiency (up to 32\%) as compared to other reagents 519 (Lipofectamine 3000, Lipofectamine 2000 and the non-liposomal PEI-based reagents 520 Transporter ${ }^{\mathrm{TM}} 5$ and PEI25) that produced efficiencies below 20\% (Tan et al. 2019).

521 As a general guideline, using cells from the early passage was recommended to achieve good 522 transfection efficiency, especially for transfection that involves primary or stem cells (Young et al. 523 2002; Covello et al. 2014; Wang et al. 2015). Another interesting observation was that $37^{\circ} \mathrm{C}$ was 524 the optimal incubation temperature that could help reach higher transfection efficiency in primary 525 cells (Young et al. 2002). This phenomenon could be because $37^{\circ} \mathrm{C}$ is the optimal culture 526 temperature for mammalian cells (Wang, Wei, et al. 2017). Meanwhile, chemical transfection 527 appeared to be less appealing than viral and physical transfection for transfecting primary cells, 528 especially in human primary stem cells.

\section{Human vs animal cells}

531 The origin of cell lines, such as human vs. animal cell lines, may also contribute to varying degrees 532 of efficiencies when transfected using the same transfection reagents under similar conditions 533 (Kiefer et al. 2004; Kim and Eberwine 2010; Maurisse et al. 2010). In a study which involved 534 transfection into smooth muscle cells from human and rat (Kiefer et al. 2004), most of the 535 transfection reagents were reported to show higher efficiencies in transfecting rats smooth muscle 536 cells (A-10 SMCs) as compared to human aorta smooth muscle cells (HASMCs). Among the seven 537 transfection reagents tested (DAC-30, DC-30, Lipofectin, LipofectAMINEPLUS, Effectene, 538 FuGene 6 and Superfect), FuGENE 6 was concluded to produce the best transfection efficiency in 
539 both HASMCs and A-10 SMCs, but the efficiency was 4 fold lower in the former ( $\sim 10 \%$ vs $\sim 40 \%)$.

540 In both cell lines, SuperFect produced the highest cytotoxic effects, followed by DAC-30 and 541 Lipofectamine Plus, while FuGENE 6 was considered comparatively safe to the cell lines ((Kiefer 542 et al. 2004).

543 In another study which compared the transfection outcome between different cell lines from human 544 and animal origin, pig tracheal epithelial cells (PTE) was shown to be more efficiently transfected 545 than the human tracheal epithelial cell line (HTE) by transfection reagents including Effectene, 546 Lipofectamine Plus and PEI (Maurisse et al. 2010). Transfected HTE also exhibited lower viability 547 than PTE post chemical transfection (Maurisse et al. 2010). Combined findings from the two cited 548 studies (Kiefer et al. 2004; Maurisse et al. 2010) suggested that probably animal cell lines may be 549 more efficiently transfected than human cell lines.

550

551

\section{Cell lines derived from the same species}

552

553 The performance of different transfection reagents could also vary in different cell lines derived 554 from the same species. For instance, liposomal reagents were reported to exhibit higher efficiencies 555 than non-liposomal reagents in transfecting various immortalized human cell lines, including 556 HEK293, MDA-MB-231, MCF-7, A549, A673, HCT116, HeLa, HepG2, JU77, Huh-7, and HL55760 (Borawski et al. 2007; Ooi et al. 2016; Sork et al. 2016; Shi et al. 2018; Wang et al. 2018). The 558 same trend was also observed in transfection into animal cell lines involving P16 and PTE 559 (Maurisse et al. 2010), PC12 (Covello et al. 2014), bMDAM (Jensen et al. 2014), E14 and R1 cells 560 (Tamm et al. 2016).

561

562 However, non-liposomal reagents were shown to produce higher transfection efficiencies than 563 liposomal-based reagents in cell lines, including MCF-7, HepG2, 4T1, HCT116, and HEK293 564 (Yamano et al. 2010; Homann et al. 2017). In animal cell lines, non-liposomal reagents were only 565 reported to produce higher efficiency in a study that involved transfection into Z3 cell line 566 (Sandbichler et al. 2012).

567

568 In general, lipid-based or liposomal reagents demonstrated higher transfection efficiencies in most 569 studies that involved immortalized human and animal cell lines. In some cell lines such as MCF- 
570 7, HepG2, and HEK293, the comparisons between liposomal-based vs. non-liposomal-based

571 reagents were not conclusive, which may suggest that some cell lines are less selective to the type

572 of reagents for effective transfection, thereby offering researchers a wider choice of approaches to

573 opt for transfecting these cells.

574

575 On the other hand, non-liposomal reagents appeared to be comparatively safer than the liposomal-

576 based reagents (Sandbichler et al. 2012; Cheung et al. 2018). In both primary and immortalized

577 human cell lines, liposomal reagents were reported to produce more significant cytotoxic effects

578 than non-liposomal reagents (Kiefer et al. 2004; Yamano et al. 2010; Homann et al. 2017; Cheung

579 et al. 2018; Wang et al. 2018). Consistent with the observations, liposomal-based reagents were

580 also reported to cause higher toxicities in the animal cells, the studies by (Sandbichler et al. 2012;

581 Covello et al. 2014).

582 Adherent vs suspension cells

583

584 Suspension cells are commonly known as being more challenging to be transfected than adherent 585 cells due to reduced potential attachment of transfection complex to the suspension cells' surface 586 (Basiouni et al. 2012). However, a study comparing the efficiencies of Xfect, Lipofectamine 2000, 587 Nanofectamin, TransIT-X2, and TransIT-2020 showed that all reagents except Xfect showed 588 higher efficiency transfecting suspension cells as compared to adherent cells (Tamm et al. 2016). 589 However, the reasons underlying the opposing observations remain largely unclear and may be 590 further explored in the future.

591

592 4.1.2.3 The ratio of nucleic acids to transfection reagents

593 The ratio of nucleic acids to transfection reagents also plays a role in influencing transfection 594 efficiency (Arnold et al. 2006; Shi et al. 2018). In a study involving primary human myoblasts, the 595 effect of transfection efficiencies was compared using different nucleic acid ratios to transfection 596 reagents including FuGENE 6, Effectene, and ExGen 500 (a PEI-based reagent) (Arnold et al. 597 2006). One remarkable finding from the study was that transfection efficiency might not 598 necessarily correlate directly to the reagent volume used. For instance, the ratio of $2 \mu \mathrm{g}$ of DNA to $5995 \mu \mathrm{L}$ of FuGENE 6 reagent was shown to produce the best transfection efficiency, whereas lower 600 or higher DNA to reagent ratios did not improve the efficiency (Arnold et al. 2006). A similar 
601 finding was also observed in another study involving transfection into human gastric 602 adenocarcinoma cell line whereby the optimum transfection efficiency was not achieved using the 603 highest transfection reagent to DNA ratio volume tested among a range of combinations (Gharaati604 Far et al. 2018).

605

606 The use of disproportionate and high transfection reagent volume would cause unwanted 607 cytotoxicity that reduces the overall transfection outcome (Arnold et al. 2006; Gharaati-Far et al. 608 2018). Therefore, determining an appropriate nucleic acid to reagent ratio is an important step in 609 initiating a new transfection study to achieve high transfection efficiency and low cytotoxicity 610 (Gharaati-Far et al. 2018; Shi et al. 2018).

611

612

\subsubsection{Other factors}

613

614 Serum-reduced or serum-free media are normally recommended in transfection involving cationic 615 transfection reagents such as Lipofectamine (Wallenstein et al. 2010), HiperFect (Diener et al. 616 2015), and EndofectinMax (Shi et al. 2020). Such transfection activities entail cationic liposome617 DNA complexes formation, which requires the interaction between positively-charged liposomal 618 molecules and negatively charged nuclei acids (Son et al. 2000). As such, the presence of 619 negatively charged molecules in serum could potentially affect the complex interactions, thereby 620 affecting transfection efficiency (Simoes et al. 2000; Misra et al. 2013). However, the presence of $62110 \%$ serum was found to result in higher transfection efficiencies in MCF-7, HeLa, C2C12, and 622 MC3T3 transfected with FuGENE HD, jetPEI, Lipofectamine 2000, and Arrest-In (Yamano et al. 623 2010). It was suggested that a minimal amount of serum in transfection could improve inter-surface 624 interaction between the transfection complexes and its host cell surface by modulating the zeta 625 potential of the transfection complexes (Yamano et al. 2010).

627 On the other hand, freeze-thawing of transfection reagents was suggested as another potential factor 628 that may influence transfection efficiency. Lipofectamine 2000 reagent that underwent at least one 629 freeze thaw cycle produced superior transfection efficiency in the cell lines HEK293, Neuro2a, $630 \mathrm{C} 2 \mathrm{C} 12$ myoblasts and myotubes, hTERT MSC, SMA, and HepG2 as compared to its nonfrozen 631 control, without a compromise in cell viability (Sork et al. 2016). 
632 A possible explanation for this is that freeze-thawing could enhance molecular rearrangement 633 dispersion, thereby allowing a higher dispersion rate that allows maximal contact between the 634 nucleic acids to form more transfection complex (Sork et al. 2016). However, more studies are 635 needed to support this practice as freeze-thaw process was also suggested to cause recrystallization that could damage some chemicals' structures (Cao et al. 2003).

637

638 639

Factors affecting transfection efficiencies of the physical or mechanical transfection depends largely on the principles underlying these methods (Table 3). For instance, the electroporation technique relies on an electrical field to increase the host cell membrane's permeability to internalize foreign nucleic acids (Sherba et al. 2020). As such, the voltage and duration during the electroporation process are important factors that determine the success of electroporation. Prolonged electroporation with high voltage applied could potentially lead to cell damage and reduce transfection efficiency (Molnar et al. 2004). The electro-transfection efficiency can also be improved by increasing the number of electric pulses, but this may reduce the cell viability (Chopra et al. 2020). On the other side, the electro-transfection efficiency is dependent on the type of cell used and the electroporation condition should be optimized whenever a new cell type is going to be electro-transfected (Potter and Heller 2003). Some cell like T lymphocyte, might be poorly transfected even a standard electroporation condition is being applied while electro-transfection of fibroblasts could produce generally good transfection outcome (Potter and Heller 2003).

The electroporation buffer's composition is another critical parameter that influences transfection efficiency. ATPase inhibitor such as lidocaine in the electroporation buffer was reported to improve cell viability post-electroporation while the use of $\mathrm{K}^{+}$-based buffer resulted in better transfection efficiency than $\mathrm{Mg}^{2+}$-based buffer. $\mathrm{Mg}^{2+}$ ions were hypothesized to play a key role in activating ATPases to restore the ionic homeostasis post-electroporation to minimize cell death but could potentially reduce the transfection efficiency (Sherba et al. 2020). Therefore, a suitable recipe of electroporation buffer consisting of various components should be optimized to ensure a balance between transfection efficiency and cell viability post-electroporation is well-maintained (Sherba et al. 2020). Besides, the size and concentration of the vector should be carefully selected during electroporation. Large plasmid size was reported to reduce electroporation transfection 
663 (Molnar et al. 2004; Hornstein et al. 2016). In another study, the efficiencies of electroporation 664 transfection in dental follicle cells gradually improved as plasmid concentrations increased in the 665 range between 0.02 and $0.26 \mu \mathrm{g} / \mu \mathrm{l}$. However, not only did efficiency not improve, cell survival 666 also declined post-electroporation with further increment of plasmid concentration to $0.3 \mu \mathrm{g} / \mu \mathrm{l}$ 667 (Yao et al. 2009). In circumstances when low electric pulse number is used, a high plasmid DNA 668 concentration can be applied to compensate the low number of electric pulses to achieve a good 669 electro-transfection efficiency (Chopra et al. 2020).

670 In laser-assisted transfection, density and duration of laser-irradiation used to deliver foreign 671 nucleic acids into the host cells would primarily affect the success of transfection (Stevenson et al. 672 2006; Tsen et al. 2009). Higher laser power and prolonged exposure to laser do not necessarily 673 warrant good efficiency. In fact, moderate (Stevenson et al. 2006) to low laser power and short 674 exposure to laser-irradiation (Tsen et al. 2009) showed superior efficiency and sustained cell 675 survival compared to more prolonged exposure and higher laser power during laser-assisted 676 transfections. Besides, the efficiency of laser-assisted transfection can be enhanced by increasing 677 the number of laser pulse (Terakawa et al. 2006). The use of different cell types during laser678 assisted transfection would also show different transfection efficiencies. For instance, in a study 679 (Terakawa et al. 2006) which compared the laser-assisted transfection efficiencies between five 680 different cell types, it was demonstrated that laser-assisted transfection of HeLa cells produced 681 highest transfection efficiency while CHO and human glioma cells showed relatively lower laser682 assisted transfection efficiencies.

683 Ultrasound-assisted transfection involves creating tiny pores on the host cell membrane to 684 facilitate the delivery of nucleic acids, including DNAs and RNAs (Tomizawa et al. 2013). Similar 685 to the former strategies, exposure duration, pulse number, and density of ultrasound irradiation 686 were also reported to be proportionately associated with transfection efficiency up to a threshold 687 value (Jr. et al. 2006; Kinoshita and Hynynen 2007; Zhou et al. 2012). Beyond a tolerance limit, 688 cell survival and transfection efficiency may decline. Likewise, increasing the amount of nucleic 689 acids was also shown to improve transfection efficiency of ultrasound-assisted transfection (Zhou 690 et al. 2012). In the same study, transfecting human 293T cells cultured in suspension was claimed 691 to be easier than transfecting the same cell type grown as adherent culture (Zhou et al. 2012). 692 However, this observation did not agree with the findings from another study, which reported no 
693 significant difference in the number of the transfected rat cells cultured in either suspension or 694 monolayer conditions (Kinoshita and Hynynen 2007). Remarkably, the latter study also reported 695 that rat cells grown as monolayer culture maintained higher cell viability post-transfection 696 (Kinoshita and Hynynen 2007). Nevertheless, discordant findings from these two studies suggest 697 that the optimal culture condition for sonoporation may vary with different cell lines used. In 698 another study (Jr. et al. 2006), it was shown that sono-transfection efficiency varied with different 699 cell types being used and the sono-transfection of Hela and T-24 cell lines showed better 700 efficiencies than PC-3, U937 and Meth A cell lines. Therefore, the choice of cell type is another 701 factor which could influence sonoporation transfection efficiency (Jr. et al. 2006).

702 Magnetic-assisted transfection or magnetofection is another non-viral physical transfection 703 approach and it can be used to deliver either metal-coated nucleic acids complex or magnetic704 conjugated AAV vector into the host cell (Mykhaylyk et al. 2007). There are two ways by which magnet can assist in cell transfection, namely, oscillating and static condition. In oscillating 706 magnetofection, a magnet is placed near the host cell and moved side-by-side to drag metal-coated nucleic acids nanoparticles complex onto the host cell surface to facilitate endocytosis mechanically. In contrast, static magnetofection does not involve such steps (Fouriki et al. 2010). The oscillating system was claimed to demonstrate better transfection efficiency than the static system and sometimes superior to chemical transfection (Fouriki et al. 2010). Besides, the distance between cells and magnet could also affect transfection efficiency, whereby a shorter distance will generally result in higher transfection efficiency (Fouriki et al. 2010). Interestingly, surface modification of magnetic nanoparticles had also been shown to improve the efficiency of magnetassisted transfection. For instance, modifying the surface of $\mathrm{Fe} 3 \mathrm{O} 4$ nanoparticles for gene delivery with PEI enhanced plasmid DNA binding affinity to host cell, thereby improving the transfection outcome (Wang et al. 2014). Other factors which could influence the efficiency of magnetofection include cell types being used (Mykhaylyk et al. 2007) and number of pulses (Kardos and Rabussay

718 2012). For example, the use of magetofection to transfect human lung epithelial cells might 719 produce better transfection efficiency than Jurkat cells (Mykhaylyk et al. 2007), and the use of double magnetic pulse could increase the transfection efficiency by twice as compared to single magnetic pulse in delivery the specific plasmid DNA in vivo (Kardos and Rabussay 2012). 
722 Gene injection involves direct delivery of a desired nucleic acid material into the host cells' nucleus

723 via injection. This method serves as a good alternative when cell transfection is challenging,

724 especially when genetic modification of the host cell is required (Chow et al. 2016). Like other

725 non-viral genes delivery methods, there is no single method that can fit all different cell types

726 (Mellott et al. 2013) and the selection of a suitable cell type and nucleic acid size are vital to ensure

727 the success of gene injection. For example, a previous study has reported the successful generation

728 of transgene mice cell line that expressed the cre recombinase (size $\sim 1000 \mathrm{bp}$ ) (Dahlhoff et al.

729 2012). On the other hand, in a in vivo study, the number of mice muscle fibers expressing transgene

730 correlated with the number of injections and the dosages of the administered plasmid (Wells et al.

731 1998). This was further supported by another in vitro study, which reported that the number of the

732 host cells expressing a reporter gene was closely correlated to the amount of nucleic acids injected 733 into the cells (Chow et al. 2016). Besides, the size, shape and the presence of additional coating 734 on the microneedles would also affect the efficiency of gene injection as it has been reported that 735 small size microneedles $(<10 \mu \mathrm{m})$ coated with microparticles were able to suffessfully deliver the 736 desired cargo to the stratum corneum layer of the skin (Mellott et al. 2013)

\section{Conclusion}

738 There is no single or universal transfection strategy that is apt for all cell lines and experimental aims. Apart from the experimental budget and the availability of required facilities, the choice for an optimal transfection approach or strategy depends on factors including the type and origin of cells and the form of nucleic acids to be transfected. It is also essential to consider factors that may affect transfection efficiency and cytotoxicity to the host cells and how these parameters may be assessed accurately and conveniently. Likewise, the inclusion of appropriate controls in a transfection experiment is equally important to allow a fair and unbiased assessment of the experimental outcome.

\section{References} therapeutics and a review of targeted nanoparticle delivery systems in breast cancer', Biophysical Reviews, 10(1), 69-86. 
progress.', The AAPS journal, 11(4), 671, available: http://www.ncbi.nlm.nih.gov/pubmed/19834816\%0Ahttp://www.pubmedcentral.nih.gov/art iclerender.fcgi?artid=PMC2782077.

Alabdullah, A.A., Al-Abdulaziz, B., Alsalem, H., Magrashi, A., Pulicat, S.M., Almzroua, A.A., Almohanna, F., Assiri, A.M., Al Tassan, N.A., Al-Mubarak, B.R. (2019) 'Estimating transfection efficiency in differentiated and undifferentiated neural cells', BMC Research Notes, 12, 225, available: https://doi.org/10.1186/s13104-019-4249-5.

Aldred, S.F., Collins, P., Trinklein, N. (2011) 'Identifying targets of human microRNAs with the lightSwitch luciferase assay system using 3 ' UTR-reporter constructs and a microRNA mimic in adherent cells', Journal of Visualized Experiments, 55, 3343.

Allison, S.J., Milner, J. (2014) 'RNA interference by single- and double-stranded siRNA with a DNA extension containing a 3' nuclease-resistant mini-hairpin structure', Molecular Therapy - Nucleic Acids, 3(1), e141.

Arnold, A.S., Laporte, V., Dumont, S., Appert-Collin, A., Erbacher, P., Coupin, G., Levy, R., Poindron, P., Gies, J.P. (2006) 'Comparing reagents for efficient transfection of human primary myoblasts: FuGENE 6, Effectene and ExGen 500', Fundamental and Clinical Pharmacology, 20(1), 81-89.

Attractene Transfection Reagent Handbook (2008) Qiagen [online], available: https://www.qiagen.com/us/shop/rnai/attractene-transfection-reagent/\#productdetails [accessed 11 May 2019].

Ayub, S.M.K., Ling, F.L., Too, See Cun, W. (2016) 'Optimisation of miRNA transfection conditions and studying the effect of miRNA down-regulation on CKa gene expression in HepG2 cell line', Health and Environment Journal, 7(1), 101-123.

Balak, J.R.A., de Graaf, N., Zaldumbide, A., Rabelink, T.J., Hoeben, R.C., de Koning, E.J.P., Carlotti, F. (2019) 'Highly efficient ex vivo lentiviral transduction of primary human pancreatic exocrine cells', Scientific Reports, 9, 15870.

Balazs, D.A., Godbey, W. (2011) 'Liposomes for use in gene delivery', Journal of Drug Delivery, 2011, 326497.

Basiouni, S., Fuhrmann, H., Schumann, J. (2012) 'High-efficiency transfection of suspension cell lines', BioTechniques, 53(2), 1-4.

Bauler, M., Roberts, J.K., Wu, C.-C., Fan, B., Ferrara, F., Yip, B.H., Diao, S., Kim, Y.-I., Moore, J., Zhou, S., Wielgosz, M.M., Ryu, B., Throm, R.E. (2020) 'Production of lentiviral vectors using suspension cells grown in serum-free media', Molecular Therapy - Methods and Clinical Development, 17, 58-68, available: https://doi.org/10.1016/j.omtm.2019.11.011.

Bell, N.M., Micklefield, J. (2009) 'Chemical modification of oligonucleotides for therapeutic, bioanalytical and other applications’, ChemBioChem, 10(17), 2691-2703.

Borawski, J., Lindeman, A., Buxton, F., Labow, M., Gaither, L.A. (2007) 'Optimization procedure for small interfering RNA transfection in a 384-well format', Journal of Biomolecular Screening, 12(4), 546-559. 
791

792

793

794

795

796

797

798

799

800

801

802

803

804

805

806

807

808

809

810

811

812

813

814

815

816

817

818

819

820

821

822

823

824

825

826

827

828

829

830

Brunner, S., Sauer, T., Carotta, S., Cotten, M., Saltik, M., Wagner, E. (2000) 'Cell cycle dependence of gene transfer by lipoplex , polyplex and recombinant adenovirus', Gene Therapy, 7, 401-407.

Canoy, R.J., André, F., Shmakova, A., Wiels, J., Lipinski, M., Vassetzky, Y., Germini, D. (2020) 'Easy and robust electrotransfection protocol for ef fi cient ectopic gene expression and genome editing in human B cells', Gene Therapy, (Online ahead of print), available: http://dx.doi.org/10.1038/s41434-020-00194-x.

Cao, E., Chen, Y., Cui, Z., Foster, P.R. (2003) 'Effect of freezing and thawing rates on denaturation of proteins in aqueous solutions', Biotechnology and Bioengineering, 82(6), 684-690.

Chan, J.A., Krichevsky, A.M., Kosik, K.S. (2005) 'MicroRNA-21 is an antiapoptotic factor in human glioblastoma cells', Cancer Resesearch, 65(14), 6029-33, available: http:/www.ncbi.nlm.nih.gov/pubmed/16024602.

Chen, X., Gu, S., Chen, B.-F., Shen, W.-L., Yin, Z., Xu, G.-W., Hu, J.-J., Zhu, T., Li, G., Wan, C., Ouyang, H.-W., Lee, T.-L., Chan, W.-Y. (2015) 'Nanoparticle delivery of stable miR199a-5p agomir improves the osteogenesis of human mesenchymal stem cells via the HIF1a pathway', Biomaterials, 53, 239-250, available: http://dx.doi.org/10.1016/j.biomaterials.2015.02.071.

Cheung, W.Y., Hovey, O., Gobin, J.M., Muradia, G., Mehic, J., Westwood, C., Lavoie, J.R. (2018) 'Efficient nonviral transfection of human bone marrow mesenchymal stromal cells shown using placental growth factor overexpression', Stem Cells International, 2018, 1310904.

Chopra, S., Ruzgys, P., Maciulevičius, M., Jakutavičiute, M., Šatka, S. (2020) 'Investigation of plasmid DNA delivery and cell viability dynamics for optimal cell electrotransfection in vitro', Applied Sciences, 10(17), 6070.

Chow, Y.T., Chen, S., Wang, R., Liu, C., Kong, C.-W., Li, R.A., Cheng, S.H., Sun, D. (2016) 'Single cell transfection through precise microinjection with quantitatively controlled injection volumes', Scientific Reports, 6, 24127, available: http://dx.doi.org/10.1038/srep24127.

Chuma, S., Nakano, T. (2013) 'piRNA and spermatogenesis in mice', Philosophical Transactions of the Royal Society B: Biological Sciences, 368(1609), 20110338.

Colosimo, A., Goncz, K.K., Holmes, A.R., Kunzelmann, K., Novelli, G., Malones, R.W., Bennett, M.J., Gruenert, D.C. (2000) 'Transfer and expression of foreign genes in mammalian cells', BioTechniques, 29(2), 314-331.

Covello, G., Siva, K., Adami, V., Denti, M.A. (2014) 'An electroporation protocol for efficient DNA transfection in PC12 cells', Cytotechnology, 66(4), 543-553.

Dahlhoff, M., Grzech, M., Habermann, F.A., Wolf, E., Schneider, M.R. (2012) 'A transgenic mouse line expressing cre recombinase in pancreatic $\beta$-cells', Genesis, 50(5), 437-442.

Delrue, I., Pan, Q., Baczmanska, A.K., Callens, B.W., Verdoodt, L.L.M. (2018) 'Determination of the selection capacity of antibiotics for gene selection', Biotechnology Journal, 13(8),

PeerJ reviewing PDF | (2020:06:49567:3:0:NEW 23 Feb 2021) 
831

832

833

834

835

836

837

838

839

840

841

842

843

844

845

846

847

848

849

850

851

852

853

854

855

856

857

858

859

860

861

862

863

864

865

866

867

868

869

e1700747.

Denning, W., Das, S., Guo, S., Xu, J., Kappes, J.C., Hel, Z. (2013) 'Optimization of the transductional efficiency of lentiviral vectors: effect of sera and polycations', Molecular Biotechnology, 53(3), 308-314, available: http://www.aerzteblatt.de/int/article.asp?id=27586.

Deriziotis, P., Graham, S.A., Estruch, S.B., Fisher, S.E. (2014) 'Investigating protein-protein interactions in live cells using bioluminescence resonance energy transfer', Journal of Visualized Experiments, 87, 51438.

Du, X., Wang, J., Zhou, Q., Zhang, L., Wang, S., Zhang, Z., Yao, C. (2018) 'Advanced physical techniques for gene delivery based on membrane perforation', Drug Delivery, 25(1), 15161525, available: https://doi.org/10.1080/10717544.2018.1480674.

Dufès, C., Uchegbu, I.F., Schätzlein, A.G. (2005) 'Dendrimers in gene delivery', Advanced Drug Delivery Reviews, 57(15), 2177-2202.

Duportet, X., Wroblewska, L., Guye, P., Li, Y., Eyquem, J., Rieders, J., Rimchala, T., Batt, G., Weiss, R. (2014) 'A platform for rapid prototyping of synthetic gene networks in mammalian cells', Nucleic Acids Research, 42(21), 13440-13451.

Edvard Smith, C.I., Zain, R. (2019) 'Therapeutic oligonucleotides: State of the art', Annual Review of Pharmacology and Toxicology, 59, 605-630.

Elgundi, Z., Sifniotis, V., Reslan, M., Cruz, E., Kayser, V. (2017) 'Laboratory scale production and purification of a therapeutic antibody', Journal of Visualized Experiments, 119, e55153.

Elmén, J., Thonberg, H., Ljungberg, K., Frieden, M., Westergaard, M., Xu, Y., Wahren, B., Liang, Z., Ørum, H., Koch, T., Wahlestedt, C. (2005) 'Locked nucleic acid (LNA) mediated improvements in siRNA stability and functionality', Nucleic Acids Research, 33(1), 439447.

Ervin, E.H., Pook, M., Teino, I., Kasuk, V., Trei, A., Pooga, M., Maimets, T. (2019) 'Targeted gene silencing in human embryonic stem cells using cell-penetrating peptide PepFect', Stem Cell Research and Therapy, 10(1), 43.

Fabani, M.M., Gait, M.J. (2008) 'miR-122 targeting with LNA/2'-O-methyl oligonucleotide mixmers, peptide nucleic acids (PNA), and PNA-peptide conjugates', $R N A, 14(2), 336-346$.

Fakhiri, J., Schneider, M.A., Puschhof, J., Stanifer, M., Schildgen, V., Holderbach, S., Voss, Y., El Andari, J., Schildgen, O., Boulant, S., Meister, M., Clevers, H., Yan, Z., Qiu, J., Grimm, D. (2019) 'Novel chimeric gene therapy vectors based on adeno-associated virus and four different mammalian bocaviruses', Molecular Therapy - Methods and Clinical Development, 12, 202-222, available: https://doi.org/10.1016/j.omtm.2019.01.003.

Faltin, B., Zengerle, R., Vonstetten, F. (2013) 'Current methods for fluorescence-based universal sequence-dependent detection of nucleic acids in homogenous assays and clinical applications', Clinical Chemistry, 59(11), 1567-1582.

Fernández-frías, I., Pérez-luz, S., Díaz-nido, J. (2020) 'Enhanced production of Herpes Simplex Virus 1 amplicon vectors by gene modification and optimization of packaging cell growth 
870

871

872

873

874

875

876

877

878

879

880

881

882

883

884

885

886

887

888

889

890

891

892

893

894

895

896

897

898

899

900

901

902

903

904

905

906

907

medium', Molecular Therapy: Methods \& Clinical Development, 17, 491-496, available: https://doi.org/10.1016/j.omtm.2020.03.005.

$\mathrm{Fu}$, A., Jacobs, D.I., Zhu, Y. (2014) 'Epigenome-wide analysis of piRNAs in gene-specific DNA methylation', RNA Biology, 11(10), 1301-1312.

$\mathrm{Fu}, \mathrm{Y}$., Chen, J., Huang, Z. (2019) 'Recent progress in microRNA-based delivery systems for the treatment of human disease', ExRNA, 1, 24.

Gam, J.J., DiAndreth, B., Jones, R.D., Huh, J., Weiss, R. (2019) ‘A “poly-transfection” method for rapid, one-pot characterization and optimization of genetic systems', Nucleic Acids Research, 47(18), e106.

Gharaati-Far, N., Tohidkia, M.R., Dehnad, A., Omidi, Y. (2018) 'Efficiency and cytotoxicity analysis of cationic lipids-mediated gene transfection into AGS gastric cancer cells', Artificial Cells, Nanomedicine, and Biotechnology, 46(5), 1001-1008, available: https://doi.org/10.1080/21691401.2017.1355311.

Godbey, W.T., Zhang, X., Chang, F. (2008) 'The importance of and a method for including transfection efficiency into real-time PCR data analyses', Biotechnology and Bioengineering, 100(4), 765-772.

Groll, A. Von, Levin, Y., Barbosa, M.C., Ravazzolo, A.P. (2006) 'Linear DNA low efficiency transfection by liposome can be improved by the use of cationic lipid as charge neutralizer', Biotechnology Progress, 22(4), 1220-1224.

Grünweller, A., Hartmann, R.K. (2007) 'Locked nucleic acid oligonucleotides: The next generation of antisense agents?', BioDrugs, 21(4), 235-243.

Guo, L., Wang, L., Yang, R., Feng, R., Li, Z., Zhou, X., Dong, Z., Ghartey-Kwansah, G., Xu, M.M., Nishi, M., Zhang, Q., Isaacs, W., Ma, J., Xu, X. (2017) 'Optimizing conditions for calcium phosphate mediated transient transfection', Saudi Journal of Biological Sciences, 24(3), 622-629, available: http://dx.doi.org/10.1016/j.sjbs.2017.01.034.

Hamann, A., Nguyen, A., Pannier, A.K. (2019) 'Nucleic acid delivery to mesenchymal stem cells: A review of nonviral methods and applications', Journal of Biological Engineering, 13,7 .

Hannig, G., Jany, C. (2013) 'Co-transfection of plasmid DNA', BioTechniques, 54(1), 47.

Hardee, C.L., Arévalo-Soliz, L.M., Hornstein, B.D., Zechiedrich, L. (2017) 'Advances in nonviral DNA vectors for gene therapy', Genes, 8(2), 65.

Hillebrand, F., Ostermann, P.N., Müller, L., Degrandi, D., Erkelenz, S., Widera, M., Pfeffer, K., Schaal, H. (2019) 'Gymnotic delivery of LNA mixmers targeting viral sres induces HIV-1 mRNA degradation', International Journal of Molecular Sciences, 20(5), 1088.

Hindmarsh, P., Leis, J. (1999) 'Retroviral DNA integration.', Microbiology and Molecular Biology Reviews, 63(4), 836-843.

HiPerFect Transfection Reagent Handbook (2010) Qiagen [online], available: https://www.qiagen.com/us/resources/download.aspx?id=c475824e-3da5-40b6-9870- 
1752ffb015a6\&lang=en [accessed 28 Feb 2020].

Ho, H.-Y., Cheng, M.-L., Wang, Y.-H., Chiu, D.T.-Y. (2006) 'Flow cytometry for assessment of the efficacy of siRNA', Cytometry Part A, 69(10), 1054-1061.

Homann, S., Hofmann, C., Gorin, A.M., Nguyen, H.C.X., Huynh, D., Hamid, P., Maithel, N., Yacoubian, V., Mu, W., Kossyvakis, A., Roy, S. Sen, Yang, O.O., Kelesidis, T. (2017) 'A novel rapid and reproducible flow cytometric method for optimization of transfection efficiency in cells', PLoS ONE, 12(9), e0182941.

Horibe, T., Torisawa, A., Akiyoshi, R., Hatta-Ohashi, Y., Suzuki, H., Kawakami, K. (2014) 'Transfection efficiency of normal and cancer cell lines and monitoring of promoter activity by single-cell bioluminescence imaging', Luminescence, 29(1), 96-100.

Hornstein, B.D., Roman, D., Arévalo-Soliz, L.M., Engevik, M.A., Zechiedrich, L. (2016) 'Effects of circular DNA length on transfection efficiency by electroporation into HeLa cells', PLoS ONE, 11(12), e0167537.

Hu, G., Zhao, X., Wang, C., Geng, Y., Zhao, J., Xu, J., Zuo, B., Zhao, C., Wang, C., Zhang, X. (2017) 'MicroRNA-145 attenuates TNF- $\alpha$-driven cartilage matrix degradation in osteoarthritis via direct suppression of MKK4', Cell Death \& Disease, 8(10), e3140.

Hunt, M.A., Currie, M.J., Robinson, B.A., Dachs, G.U. (2010) 'Optimizing transfection of primary human umbilical vein endothelial cells using commercially available chemical transfection reagents', Journal of Biomolecular Techniques, 21(2), 66-72.

Igoucheva, O., Alexeev, V., Yoon, K. (2006) 'Differential cellular responses to exogenous DNA in mammalian cells and its effect on oligonucleotide-directed gene modification', Gene Therapy, 13(3), 266-275.

Ikeda, Y., Collins, M., Radcliffe, P., Mitrophanous, K., Takeuchi, Y. (2002) 'Gene transduction efficiency in cells of different species by HIV and EIAV vectors', Gene Therapy, 9(14), 932-938.

Ishida, M., Selaru, F.M. (2012) 'miRNA-Based Therapeutic Strategies', Current Anesthesiology Reports, 1(1), 63-70.

Jensen, E.C. (2013) 'Quantitative analysis of histological staining and fluorescence using ImageJ', The Anatomical Record, 296(3), 378-381.

Jensen, K., Anderson, J.A., Glass, E.J. (2014) 'Comparison of small interfering RNA (siRNA) delivery into bovine monocyte-derived macrophages by transfection and electroporation', Veterinary Immunology and Immunopathology, 158(3-4), 224-232.

Jin, H.Y., Gonzalez-Martin, A., Miletic, A. V., Lai, M., Knight, S., Sabouri-Ghomi, M., Head, S.R., Macauley, M.S., Rickert, R.C., Xiao, C. (2015) 'Transfection of microRNA mimics should be used with caution', Frontiers in Genetics, 6, 340.

Jin, L., Zeng, X., Liu, M., Deng, Y., He, N. (2014) 'Current progress in gene delivery technology based on chemical methods and nano-carriers', Theranostics, 4(3), 240-255.

Jordan, E.T., Collins, M., Terefe, J., Ugozzoli, L., Rubio, T. (2008) 'Optimizing electroporation 
946

950

951

952

953

954

955

956

957

958

959

960

961

962

963

964

965

966

967

968

969

970

971

972

973

974

975

976

977

978

979

980

981

982

983

conditions in primary and other difficult-to-transfect cells', Journal of Biomolecular Techniques, 19(5), 328-334.

Jr., L.B.F., Ogawa, R., Tachibana, K., Kondo, T. (2006) 'Optimized ultrasound-mediated gene transfection in cancer cells', Cancer Science, 97(10), 1111-1114.

Kamens, J. (2015) 'The Addgene repository: An international nonprofit plasmid and data resource', Nucleic Acids Research, 43(Database issue), D1152-D1157.

Karda, R., Counsell, J.R., Karbowniczek, K., Caproni, L.J., Tite, J.P., Waddington, S.N. (2019) 'Production of lentiviral vectors using novel, enzymatically produced, linear DNA', Gene Therapy, 26(3-4), 86-92, available: http://dx.doi.org/10.1038/s41434-018-0056-1.

Kardos, T.J., Rabussay, D.P. (2012) 'Contactless magneto-permeabilization for intracellular plasmid DNA delivery in vivo', Human Vaccines and Immunotherapeutics, 8(11), 17071713.

Kaufman, W.L., Kocman, I., Agrawal, V., Rahn, H., Besser, D., Gossen, M. (2008) 'Homogeneity and persistence of transgene expression by omitting antibiotic selection in cell line isolation', Nucleic Acids Research, 36(17), e111.

Keller, A., Maeß, M.B., Schnoor, M., Scheiding, B., Lorkowski, S. (2018) 'Transfecting macrophages', Methods in Molecular Biology, 1784, 187-195.

Keswani, R.K., Pozdol, I.M., Pack, D.W. (2013) 'Design of hybrid lipid/retroviral-like particle gene delivery vectors', Molecular Pharmacology, 10(5), 1725-1735, available: https://www.ncbi.nlm.nih.gov/pmc/articles/PMC3624763/pdf/nihms412728.pdf.

Khamlichi, C. El, Reverchon-assadi, F., Hervouet-Coste, N., Blot, L., Reiter, E., Morisset-Lopez, S. (2019) 'Bioluminescence resonance energy transfer as a method to study protein-protein Interactions: Application to G protein coupled receptor biology', Molecules, 24(3), 537.

Kiefer, K., Clement, J., Garidel, P., Peschka-Süss, R. (2004) 'Transfection efficiency and cytotoxicity of nonviral gene transfer reagents in human smooth muscle and endothelial cells', Pharmaceutical Research, 21(6), 1009-1017.

Kim, T.K., Eberwine, J.H. (2010) 'Mammalian cell transfection: The present and the future', Analytical and Bioanalytical Chemistry, 397(8), 3173-3178.

Kinoshita, M., Hynynen, K. (2007) 'Key factors that affect sonoporation efficiency in in vitro settings; The importance of standing wave in sonoporation', Biochemical and Biophysical Research Communications, 359(4), 860-865, available: file://C:/Users/ASUS/Desktop/Rujukan PhD/Dev of drug R cell line/nihms579608.pdf.

Kretzmann, J.A., Evans, C.W., Norret, M., Blancafort, P., Iyer, K.S. (2018) 'Non-viral methodology for efficient co-transfection', Methods in Molecular Biology, 1767, 241-254.

Krützfeldt, J., Rajewsky, N., Braich, R., Rajeev, K.G., Tuschl, T., Manoharan, M., Stoffel, M. (2005) 'Silencing of microRNAs in vivo with "antagomirs"', Nature, 438(7068), 685-689.

Kwak, S.Y., Han, H.D., Ahn, H.J. (2019) 'A T7 autogene-based hybrid mRNA/DNA system for long-term shRNA expression in cytoplasm without inefficient nuclear entry', Scientific 
984

985

986

987

988

989

990

991

992

993

994

995

996

997

998

999

1000

1001

1002

1003

1004

1005

1006

1007

1008

1009

1010

1011

1012

1013

1014

1015

1016

1017

1018

1019

1020

1021

1022

Reports, 9(1), 2293.

Lam, J.K., Chow, M.Y., Zhang, Y., Leung, S.W. (2015) 'siRNA versus miRNA as therapeutics for gene silencing', Molecular Therapy - Nucleic Acids, 4, e252.

Lee, C.S., Bishop, E.S., Zhang, R., Yu, X., Farina, E.M., Yan, S., Zhao, C., Zeng, Z., Shu, Y., Wu, X., Lei, J., Li, Y., Zhang, W., Yang, C., Wu, K., Wu, Y., Ho, S., Athiviraham, A., Lee, M.J., Moriatis, J., Reid, R.R., He, T.-C. (2017) 'Adenovirus-mediated gene delivery: Potential applications for gene and cell-based therapies in the new era of personalized medicine', Genes \& Diseases, 4(2), 43-63.

Lee, E.J., Banerjee, S., Zhou, H., Jammalamadaka, A., Arcila, M., Manjunath, B.S., Kosik, K.S. (2011) 'Identification of piRNAs in the central nervous system', $R N A, 17(6), 1090-1099$.

Li, D., Wang, M. (2012) 'Construction of a bicistronic vector for the co-expression of two genes in Caenorhabditis elegans using a newly identified IRES', BioTechniques, 52(3), 173-176.

Li, J., Chen, Y., Qin, X., Wen, J., Ding, H., Xia, W., Li, S., Su, X., Wang, W., Li, H., Zhao, Q., Fang, T., Qu, L., Shao, N. (2014) 'MiR-138 downregulates miRNA processing in HeLa cells by targeting RMND5A and decreasing Exportin-5 stability', Nucleic Acids Research, 42(1), 458-474.

Liang, S., Knight, M., Jolly, E.R. (2013) 'Polyethyleneimine mediated DNA transfection in Schistosome parasites and regulation of the WNT signaling pathway by a dominantnegative SmMef2', PLoS Neglected Tropical Diseases, 7(7), e2332.

Liang, W., Mason, A.J., Lam, J.K.W. (2013) 'Western blot evaluation of siRNA delivery by pH responsive peptides', Methods in Molecular Biology, 986, 73-87, available: http://link.springer.com/10.1007/978-1-62703-311-4.

Liang, X., Hart, C.E., Crooke, S.T. (2013) 'Transfection of siRNAs can alter miRNA levels and trigger non-specific protein degradation in mammalian cells', Biochimica et Biophysica Acta, 1829(5), 455-468.

Liew, A., André, F.M., Lesueur, L.L., De Ménorval, M.-A., O’Brien, T., Mir, L.M. (2013)

'Robust, efficient, and practical electrogene transfer method for human mesenchymal stem cells using square electric pulses', Human Gene Therapy Methods, 24(5), 289-297.

Lin, W.-W., Chen, I.-J., Cheng, T.-C., Tung, Y.-C., Chu, P.-Y., Chuang, C.-H., Hsieh, Y.-C., Huang, C.-C., Wang, Y.-T., Kao, C.-H., Roffler, S.R., Cheng, T.-L. (2016) 'A secondary antibody-detecting molecular weight marker with mouse and rabbit IgG Fc linear epitopes for Western Blot analysis', PLoS ONE, 11(8), e0160418.

Lufino, M.M.P., Edser, P.A.H., Wade-Martins, R. (2008) ‘Advances in high-capacity extrachromosomal vector technology: Episomal maintenance, vector delivery, and transgene expression', Molecular Therapy, 16(9), 1525-1538, available: http://dx.doi.org/10.1038/mt.2008.156.

Maginnis, M.S. (2018) 'Virus - receptor interactions: The key to cellular invasion', Journal of Molecular Biology, 430(17), 2590-2611.

Mali, S. (2013) 'Delivery systems for gene therapy', Indian Journal of Human Genetics, 19(1), 
1023

1024

1025

1026

1027

1028

1029

1030

1031

1032

1033

1034

1035

1036

1037

1038

1039

1040

1041

1042

1043

1044

1045

1046

1047

1048

1049

1050

1051

1052

1053

1054

1055

1056

1057

1058

1059

1060

3-8.

Marjanovič, I., Kandušer, M., Miklavčič, D., Keber, M.M., Pavlin, M. (2014) 'Comparison of flow cytometry, fluorescence microscopy and spectrofluorometry for analysis of gene electrotransfer efficiency', Journal of Membrane Biology, 247(12), 1259-1267.

Maurisse, R., De Semir, D., Emamekhoo, H., Bedayat, B., Abdolmohammadi, A., Parsi, H., Gruenert, D.C. (2010) 'Comparative transfection of DNA into primary and transformed mammalian cells from different lineages’, BMC Biotechnology, 10, 9.

Mcintyre, G.J., Yu, Y.H., Lomas, M., Fanning, G.C. (2011) 'The effects of stem length and core placement on shRNA activity', BMC Molecular Biology, 12, 34, available: http://www.biomedcentral.com/1471-2199/12/34.

Meisel, J.W., Gokel, G.W. (2016) 'A simplified direct lipid mixing lipoplex preparation : Comparison and ethanol-based methods', Scientific Reports, 6, 27662, available: http://dx.doi.org/10.1038/srep27662.

Mellott, A.J., Forrest, M.L., Detamore, M.S. (2013) 'Physical non-viral gene delivery methods for tissue engineering', Annals of Biomedical Engineering, 41(3), 446-468.

Meng, L., Liu, X., Wang, Y., Zhang, W., Zhou, W., Cai, F., Li, F., Wu, J., Xu, L., Niu, L., Zheng, H. (2019) 'Sonoporation of cells by a parallel stable cavitation microbubble array', Advanced Science, 6(17), 1-17.

Merhautova, J., Demlova, R., Slaby, O. (2016) 'MicroRNA-based therapy in animal models of selected gastrointestinal cancers', Frontiers in Pharmacology, 7, 329.

Merten, O.W., Hebben, M., Bovolenta, C. (2016) 'Production of lentiviral vectors', Molecular Therapy - Methods and Clinical Development, 3, 16017.

Mitchenall, L.A., Hipkin, R.E., Piperakis, M.M., Burton, N.P., Maxwell, A. (2018) 'A rapid high-resolution method for resolving DNA topoisomers', BMC Research Notes, 11(1), 37, available: https://doi.org/10.1186/s13104-018-3147-6.

Mogler, M.A., Kamrud, K.I. (2015) 'RNA-based viral vectors RNA-based viral vectors', Expert Review of Vaccines, 14(2), 283-312.

Moher, D., Liberati, A., Tetzlaff, J., Altman, D.G., Group, T.P. (2009) 'Preferred reporting items for systematic reviews and meta-analyses: The PRISMA statement', PLoS Medicine, 6(7), e1000097.

Molnar, M.J., Gilbert, R., Lu, Y., Liu, A.-B., Guo, A., Larochelle, N., Orlopp, K., Lochmuller, H., Petrof, B.J., Nalbantoglu, J., Karpati, G. (2004) 'Factors influencing the efficacy, longevity, and safety of electroporation-assisted plasmid-based gene transfer into mouse muscles', Molecular Therapy, 10(3), 447-455, available: http://dx.doi.org/10.1016/j.ymthe.2004.06.642.

Mori, Y., Yoshida, Y., Satoh, A., Moriya, H. (2020) 'Development of an experimental method of systematically estimating protein expression limits in HEK293 cells', Scientific Reports, 10, 4798, available: http://dx.doi.org/10.1038/s41598-020-61646-3. 
1061

1062

1063

1064

1065

1066

1067

1068

1069

1070

1071

1072

1073

1074

1075

1076

1077

1078

1079

1080

1081

1082

1083

1084

1085

1086

1087

1088

1089

1090

1091

1092

1093

1094

1095

1096

1097

1098

1099

Mykhaylyk, O., Antequera, Y.S., Vlaskou, D., Plank, C. (2007) 'Generation of magnetic nonviral gene transfer agents and magnetofection in vitro', Nature Protocols, 2(10), 23912411.

Nayerossadat, N., Maedeh, T., Ali, P.A. (2012) 'Viral and nonviral delivery systems for gene delivery', Advanced Biomedical Research, 1, 27.

Nejepinska, J., Malik, R., Moravec, M., Svoboda, P. (2012) 'Deep sequencing reveals complex spurious transcription from transiently transfected plasmids', PLOS ONE, 7(8), e43283.

Niikura, Y., Kitagawa, K. (2016) 'Immunofluorescence analysis of endogenous and exogenous centromere-kinetochore proteins', Journal of Visualized Experiments, 109, 53732.

Nikol, S., Huehns, T.Y., Krausz, E., Armeanu, S., Engelmann, M.G., Winder, D., Salmons, B., Hoefling, B. (1999) 'Needle injection catheter delivery of the gene for an antibacterial agent inhibits neointimal formation', Gene Therapy, 6(5), 737-748.

Nora, C., Martins-santana, L., Maria, L., Monteiro, O. (2018) 'The art of vector engineering: towards the construction of next-generation genetic tools', Microbial Biotechnology, 12(1), $125-147$.

Nowakowski, A., Andrzejewska, A., Boltze, J., Nitzsche, F., Cui, L., Jolkkonen, J., Walczak, P., Lukomska, B., Janowski, M. (2017) 'Translation, but not transfection limits clinically relevant, exogenous mRNA based induction of alpha-4 integrin expression on human mesenchymal stem cells', Scientific Reports, 7(1), 1103, available: http://dx.doi.org/10.1038/s41598-017-01304-3.

Oh, H.-Y., Jin, X., Kim, J.-G., Oh, M.-J., Pian, X., Kim, J.-M., Yoon, M.-S., Son, C.-I., Lee, Y.S., Hong, K.-C., Kim, H., Choi, Y.-J., Whang, K.Y. (2007) 'Characteristics of primary and immortalized fibroblast cells derived from the miniature and domestic pigs', BMC Cell Biology, 8, 20.

Oh, S., Kessler, J.A. (2018) 'Design, assembly, production, and transfection of synthetic modified mRNA', Methods, 133, 29-43.

Ooi, A., Wong, A., Esau, L., Lemtiri-Chlieh, F., Gehring, C. (2016) 'A guide to transient expression of membrane proteins in HEK-293 cells for functional characterization', Frontiers in Physiology, 7, 300.

Ormeño, F., Hormazabal, J., Moreno, J., Riquelme, F., Rios, J., Criollo, A., Albornoz, A., Alfaro, I.E. (2020) 'Chaperone mediated autophagy degrades TDP-43 protein and is affected by TDP-43 aggregation', Frontiers in Molecular Neuroscience, 13, 19.

Pang, S., Xu, Y., Chen, J., Li, G., Huang, J., Wu, X. (2019) 'Knockdown of cell division cycleassociated protein 4 expression inhibits proliferation of triple negative breast cancer MDAMB-231 cells in vitro and in vivo', Oncology Letters, 17(5), 4393-4400.

Peng, L., Xiong, W., Cai, Y., Chen, Y., He, Y., Yang, J., Jin, J., Li, H. (2017) ‘A simple, rapid method for evaluation of transfection efficiency based on fluorescent dye', Bioengineered, $8(3), 225-231$.

Peralta-Zaragoza, O., Deas, J., Meneses-Acosta, A., De la O-Gómez, F., Fernández-Tilapa, G., 
1100

1101

1102

1103

1104

1105

1106

1107

1108

1109

1110

1111

1112

1113

1114

1115

1116

1117

1118

1119

1120

1121

1122

1123

1124

1125

1126

1127

1128

1129

1130

1131

1132

1133

1134

1135

1136

1137

Gómez-Cerón, C., Benítez-Boijseauneau, O., Burguete-García, A., Torres-Poveda, K., Bermúdez-Morales, V.H., Madrid-Marina, V., Rodríguez-Dorantes, M., Hidalgo-Miranda, A., Pérez-Plasencia, C. (2016) 'Relevance of miR-21 in regulation of tumor suppressor gene PTEN in human cervical cancer cells', BMC Cancer, 16(1), 1-16, available: http://dx.doi.org/10.1186/s12885-016-2231-3.

Pfeifer, A., Verma, I.M. (2001) 'Gene therapy: Promises and problems', Annual Review of Genomics and Human Genetics, 2, 177-211, available: http://www.annualreviews.org/doi/10.1146/annurev.genom.2.1.177.

Piñero, J., López-Baena, M., Ortiz, T., Cortés, F. (1997) 'Apoptotic and necrotic cell death are both induced by electroporation in HL60 human promyeloid leukaemia cells', Apoptosis, 2(3), 330-336.

Pinnapireddy, S.R., El Assy, M.R., Schlote, P., Bakowsky, U. (2019) 'Glycosylated artificial virus-like hybrid vectors for advanced gene delivery’, Polymers, 11(2), 243.

Potter, H., Heller, R. (2003) 'Transfection by electroporation', Current Protocols in Molecular Biology, CHAPTER, Unit-9.3.

Prasanna, G.L., Panda, T. (1997) 'Electroporation: Basic principles, practical considerations and applications in molecular biology', Bioprocess Engineering, 16(5), 261-264.

Pylaev, T., Vanzha, E., Avdeeva, E., Khlebtsov, B., Khlebtsov, N. (2019) 'A novel cell transfection platform based on laser optoporation mediated by Au nanostar layers', Journal of Biophotonics, 12(1), e201800166.

Qiagen miRCURY LNA Mimics and Inhibitors and Target Site Blockers Handbook (2017) Qiagen [online], available: https:/www.qiagen.com/us/shop/pcr/primer-sets/mircury-lnamirna-inhibitors/\#orderinginformation [accessed 9 May 2019].

Recillas-Targa, F. (2006) 'Multiple strategies for gene transfer, expression, knockdown, and chromatin influence in mammalian cell lines and transgenic animals', Molecular Biotechnology, 34(3), 337-354.

Repele, A., Manu (2019) 'Robust normalization of luciferase reporter data', Methods and Protocols, 2(3), 62.

Riedl, S., Kaiser, P., Raup, A., Synatschke, C., Jérôme, V., Freitag, R. (2018) 'Non-viral transfection of human T lymphocytes', Processes, 6(188), 1-17.

Roberts, P., Noerholm, M., Ståhlberg, N., Mouritzen, P., Glue, C. (2006) 'miRCURYTM LNA research tools for microRNA', Nature Methods, 3, I-II.

Roser, A.E., Gomes, L.C., Schünemann, J., Maass, F., Lingor, P. (2018) 'Circulating miRNAs as diagnostic biomarkers for Parkinson's disease’, Frontiers in Neuroscience, 12, 625.

Russell, T.A., Stefanovic, T., Tscharke, D.C. (2015) 'Engineering herpes simplex viruses by infection-transfection methods including recombination site targeting by CRISPR/Cas9 nucleases', Journal of Virological Methods, 213, 18-25, available: http://dx.doi.org/10.1016/j.jviromet.2014.11.009. 
1138

1139

1140

1141

1142

1143

1144

1145

1146

1147

1148

1149

1150

1151

1152

1153

1154

1155

1156

1157

1158

1159

1160

1161

1162

1163

1164

1165

1166

1167

1168

1169

1170

1171

1172

1173

1174

1175

1176

1177

Salim, L., Islam, G., Desaulniers, J.P. (2020) 'Targeted delivery and enhanced gene-silencing activity of centrally modified folic acid-siRNA conjugates', Nucleic Acids Research, 48(1), $75-85$.

Sandbichler, A.M., Aschberger, T., Pelster, B. (2012) 'A method to evaluate the efficiency of transfection reagents in an adherent zebrafish cell line', BioResearch Open Access, 2(1), $20-27$.

Sandhu, K.K., McIntosh, C.M., Simard, J.M., Smith, S.W., Rotello, V.M. (2002) 'Gold nanoparticle-mediated transfection of mammalian cells', Bioconjugate Chemistry, 13(1), 36.

Seo, M., Choi, J.S., Rho, C.R., Joo, C.K., Lee, S.K. (2015) 'MicroRNA miR-466 inhibits Lymphangiogenesis by targeting prospero-related homeobox 1 in the alkali burn corneal injury model', Journal of Biomedical Science, 22(1), 3.

Setten, R.L., Rossi, J.J., Han, S. (2019) 'The current state and future directions of RNAi-based therapeutics', Nature Reviews Drug Discovery, 18(6), 421-446, available: http://dx.doi.org/10.1038/s41573-019-0017-4.

Sherba, J.J., Hogquist, S., Lin, H., Shan, J.W., Shreiber, D.I., Zahn, J.D. (2020) 'The effects of electroporation buffer composition on cell viability and electro-transfection efficiency', Scientific Reports, 10(1), 3053, available: http://dx.doi.org/10.1038/s41598-020-59790-x.

Shi, B., Xue, M., Wang, Y., Wang, Y., Li, D., Zhao, X., Li, X. (2018) 'An improved method for increasing the efficiency of gene transfection and transduction.', International Journal of Physiology, Pathophysiology and Pharmacology, 10(2), 95-104, available: http://www.ncbi.nlm.nih.gov/pubmed/29755642\%0Ahttp://www.pubmedcentral.nih.gov/art iclerender.fcgi?artid=PMC5943608.

Shyamasundar, S., Lim, J.P., Bay, B.H. (2016) 'MiR-93 inhibits the invasive potential of triplenegative breast cancer cells in vitro via protein kinase WNK1', International Journal of Oncology, 49(6), 2629-2636.

Sograte-Idrissi, S., Schlichthaerle, T., Duque-Afonso, C.J., Alevra, M., Strauss, S., Moser, T., Jungmann, R., Rizzoli, S.O., Opazo, F. (2020) 'Circumvention of common labelling artefacts using secondary nanobodies', Nanoscale, 12(18), 10226-10239.

Sork, H., Nordin, J.Z., Turunen, J.J., Wiklander, O.P., Bestas, B., Zaghloul, E.M., Margus, H., Padari, K., Duru, A.D., Corso, G., Bost, J., Vader, P., Pooga, M., Smith, C.E., Wood, M.J., Schiffelers, R.M., Hällbrink, M., Andaloussi, S. EL (2016) 'Lipid-based transfection reagents exhibit cryo-induced increase in transfection efficiency', Molecular Therapy Nucleic Acids, 5(3), e290, available: http://dx.doi.org/10.1038/mtna.2016.8.

Stepanenko, A.A., Heng, H.H. (2017) 'Transient and stable vector transfection: Pitfalls, offtarget effects, artifacts', Mutation Research - Reviews in Mutation Research, 773, 91-103, available: http://dx.doi.org/10.1016/j.mrrev.2017.05.002.

Stroh, T., Erben, U., Kühl, A.A., Zeitz, M., Siegmund, B. (2010) 'Combined pulse electroporation - A novel strategy for highly efficient transfection of human and mouse cells', PLoS ONE, 5(3), 1-8.

Peer) reviewing PDF | (2020:06:49567:3:0:NEW 23 Feb 2021) 
1178

1179

1180

1181

1182

1183

1184

1185

1186

1187

1188

1189

1190

1191

1192

1193

1194

1195

1196

1197

1198

1199

1200

1201

1202

1203

1204

1205

1206

1207

1208

1209

1210

1211

1212

1213

1214

1215

1216

1217

Tamm, C., Kadekar, S., Pijuan-Galitó, S., Annerén, C. (2016) 'Fast and efficient transfection of mouse embryonic stem cells using non-viral reagents', Stem Cell Reviews and Reports, 12(5), 584-591, available: http://dx.doi.org/10.1007/s12015-016-9673-5.

Tan, S., Tao, Z., Loo, S., Su, L., Chen, X., Ye, L. (2019) 'Non-viral vector based gene transfection with human induced pluripotent stem cells derived cardiomyocytes', Scientific Reports, 9, 14404.

Terakawa, M., Sato, S., Ashida, H., Aizawa, K., Uenoyama, M., Masaki, Y., Obara, M. (2006) 'In vitro gene transfer to mammalian cells by the use of laser-induced stress waves: effects of stress wave parameters, ambient temperature, and cell type', Journal of Biomedical Optics, 11(1), 014026.

Tolstrup, N., Nielsen, P.S., Kolberg, J.G., Frankel, A.M., Vissing, H., Kauppinen, S. (2003) 'OligoDesign: Optimal design of LNA (locked nucleic acid) oligonucleotide capture probes for gene expression profiling', Nucleic Acids Research, 31(13), 3758-3762.

Tomás, H.A., Rodrigues, A.F., Carrondo, M.J.T., Coroadinha, A.S. (2018) 'LentiPro26: novel stable cell lines for constitutive lentiviral vector production', Scientific Reports, 8, 5271.

Tomizawa, M., Shinozaki, F., Motoyoshi, Y., Sugiyama, T., Yamamoto, S., Sueishi, M. (2013) 'Sonoporation: Gene transfer using ultrasound', World Journal of Methodology, 3(4), 3944.

Trans IT-X2 @ Dynamic Delivery System Protocol (2019) MirusBio [online], available: https://www.mirusbio.com/assets/protocols/ml061-transit-x2-dynamic-delivery-systemuser-protocol.pdf [accessed 4 Mar 2020].

Tsukita, S., Yamada, T., Takahashi, K., Munakata, Y., Hosaka, S., Takahashi, H., Gao, J., Shirai, Y., Kodama, S., Asai, Y., Sugisawa, T., Chiba, Y., Kaneko, K., Uno, K., Sawada, S., Imai, J., Katagiri, H. (2017) 'MicroRNAs 106b and 222 improve hyperglycemia in a mouse model of insulin-deficient diabetes via pancreatic $\beta$-cell proliferation', EBioMedicine, 15 , 163-172, available: http://repositorio.unan.edu.ni/2986/1/5624.pdf.

Tzlil, S., Kindt, J.T., Gelbart, W.M., Ben-shaul, A. (2003) 'Forces and pressures in DNA packaging and release from viral capsids', Biophysical Journal, 84(3), 1616-1627.

Valetti, S., Mura, S., Stella, B., Couvreur, P. (2013) 'Rational design for multifunctional nonliposomal lipid-based nanocarriers for cancer management: theory to practice', Journal of Nanobiotechnology, 11(Suppl 1), S6, available: http://www.jnanobiotechnology.com/content/11/S1/I6.

Vyncke, L., Masschaele, D., Tavernier, J., Peelman, F. (2019) 'Straightforward protein-protein interaction interface mapping via random mutagenesis and mammalian protein protein interaction trap (MAPPIT)', International Journal of Molecular Sciences, 20(9), 2058.

Wang, J., Wei, Y., Zhao, S., Zhou, Y., He, W., Zhang, Y., Deng, W. (2017) 'The analysis of viability for mammalian cells treated at different temperatures and its application in cell shipment', PLoS ONE, 12(4), e0176120.

Wang, T., Larcher, L.M., Ma, L., Veedu, R.N. (2018) 'Systematic screening of commonly used commercial transfection reagents towards efficient transfection of single-stranded 
1218

1219

1220

1221

1222

1223

1224

1225

1226

1227

1228

1229

1230

1231

1232

1233

1234

1235

1236

1237

1238

1239

1240

1241

1242

1243

1244

1245

1246

1247

1248

1249

1250

1251

1252

1253

1254

1255

oligonucleotides', Molecules, 23(10), 2564.

Wang, X., Xu, Z., Tian, Z., Zhang, X., Xu, D., Li, Q., Zhang, J., Wang, T. (2017) 'The EF-1 $\alpha$ promoter maintains high-level transgene expression from episomal vectors in transfected CHO-K1 cells', Journal of Cellular and Molecular Medicine, 21(11), 3044-3054.

Wang, Y., Shang, S., Li, C. (2015) 'Comparison of different kinds of nonviral vectors for gene delivery to human periodontal ligament stem cells', Journal of Dental Sciences, 10(4), 414422, available: http://dx.doi.org/10.1016/j.jds.2015.02.002.

Watson, C.N., Belli, A., Di Pietro, V. (2019) 'Small non-coding RNAs: New class of biomarkers and potential therapeutic targets in neurodegenerative disease', Frontiers in Genetics, 10, 364.

Weilin, W., Hodges, E., Redelius, J., Hoog, C. (2004) 'A novel approach for evaluating the efficiency of siRNAs on protein levels in cultured cells', Nucleic Acids Research, 32(2), e17.

Wells, D.J., Maule, J., Mcmahon, J., Mitchell, R., Damien, E., Poole, A., Wells, K.E. (1998) 'Evaluation of plasmid DNA for in vivo gene therapy: Factors affecting the number of transfected fibers', Journal of Pharmaceutical Sciences, 87(6), 763-768.

Wilczynska, A., Bushell, M. (2015) 'The complexity of miRNA-mediated repression', Cell Death and Differentiation, 22(1), 22-33, available: http://dx.doi.org/10.1038/cdd.2014.112.

Yamamoto, E., Niimi, K., Kiyono, T., Yamamoto, T., Nishino, K., Nakamura, K., Kotani, T., Kajiyama, H., Shibata, K., Kikkawa, F. (2017) 'Establishment and characterization of cell lines derived from complete hydatidiform mole', International Journal of Molecular Medicine, 40(3), 614-622.

Yamano, S., Dai, J., Moursi, A.M. (2010) 'Comparison of transfection efficiency of nonviral gene transfer reagents', Molecular Biotechnology, 46(3), 287-300.

Yang, C., Qiu, L., Xu, Z. (2011) 'Specific gene silencing using siRNA in cell culture', Methods in molecular biology, 793, 457-477.

Yao, C.P., Zhang, Z.X., Rahmanzadeh, R., Huettmann, G. (2008) 'Laser-based gene transfection and gene therapy', IEEE Transactions on Nanobioscience, 7(2), 111-119.

Yao, S., Rana, S., Liu, D., Wise, G.E. (2009) 'Improvement of electroporation to deliver plasmid DNA into dental follicle cells', Biotechnology Journal, 4(10), 1488-1496.

Ye, Q., Tian, G.-P., Cheng, H.-P., Zhang, X., Ou, X., Yu, X.-H., Tan, R.-Q., Yang, F.-Y., Gong, D., Huang, C., Pan, Y.-J., Zhang, J., Chen, L.-Y., Zhao, Z.-W., Xie, W., Li, L., Zhang, M., Xia, X.-D., Zheng, X.-L., Tang, C.-K. (2017) 'MicroRNA-134 promotes the development of atherosclerosis via the ANGPTL4/LPL pathway in Apolipoprotein E knockout mice', Journal of Atherosclerosis and Thrombosis, 25(3), 244-253.

Ylosmaki, L., Polini, B., Carpi, S., Martins, B., Smertina, E., Feola, S., Fusciello, M., Peltonen, K., Nieri, P., Ylosmaki, E., Cerullo, V. (2019) 'Harnessing therapeutic viruses as a delivery vehicle for RNA-based therapy', PLoS ONE, 14(10), e0224072. 
1256

1257

1258

1259

1260

1261

1262

1263

1264

1265

1266

1267

1268

1269

1270

1271

1272

1273

1274

1275

1276

1277

1278

1279

1280

1281

1282

1283

1284

1285

1286

1287

1288

1289

1290

1291

1292
Young, A.T.L., Lakey, J.R.T., Murray, A.G., Moore, R.B. (2002) 'Gene therapy: A lipofection approach for gene transfer into primary endothelial cells', Cell Transplantation, 11(6), 573582.

Zeitelhofer, M., Vessey, J.P., Xie, Y., Tubing, F., Thomas, S., Kiebler, M., Dahm, R. (2007) 'High-efficiency transfection of mammalian neurons via nucleofection', Nature Protocols, 2(7), 1692-1704.

Zhao, P., Zhang, Z. (2018) 'TNF- $\alpha$ promotes colon cancer cell migration and invasion by upregulating TROP-2', Oncology Letters, 15(3), 3820-3827.

Zhou, Q., Chen, J.-L., Chen, Q., Wang, X., Deng, Q., Hu, B., Guo, R.-Q. (2012) 'Optimization of transfection parameters for ultrasound/SonoVue microbubble-mediated hAng-1 gene delivery in vitro', Molecular Medicine Reports, 6(6), 1460-1464.

Zou, S., Scarfo, K., Nantz, M.H., Hecker, J.G. (2010) 'Lipid-mediated delivery of RNA is more efficient than delivery of DNA in non-dividing cells', International Journal of Pharmaceutics, 389(1-2), 232-243.

\section{Competing Interests}

The authors declare that they have no competing interests.

\section{Author Contributions}

Zhi Xiong Chong conceived and designed the contents of the paper, performed data searches, analyzed the data, prepared figures and/or tables, authored or reviewed drafts of the paper, approved the final draft.

Swee Keong Yeap conceived and designed the contents of the paper, performed data searches, analyzed the data, prepared figures and/or tables, authored or reviewed drafts of the paper, approved the final draft.

Wan Yong Ho conceived and designed the contents of the paper, analyzed the data, authored or reviewed drafts of the paper, approved the final draft.

\section{Data Availability}

The following information was supplied regarding data availability:

No raw data has been generated from the literature review.

\section{Funding}

This work was supported by FRGS grant by Ministry of Higher Education, Malaysia, grant number FRGS/1/2018/STG05/UNIM/02/1 and FRGS/1/2014/SG05/UNIM/02/1. The funders had no role in study design, data collection and analysis, decision to publish, or preparation of the manuscript. 


\section{Table $\mathbf{1}$ (on next page)}

Table 1: List of commonly used oligonucleotides in the small RNA transient transfection work

List of commonly used oligonucleotides in the small RNA transient transfection work 
Table 1: List of commonly used oligonucleotides in the small RNA transient transfection work

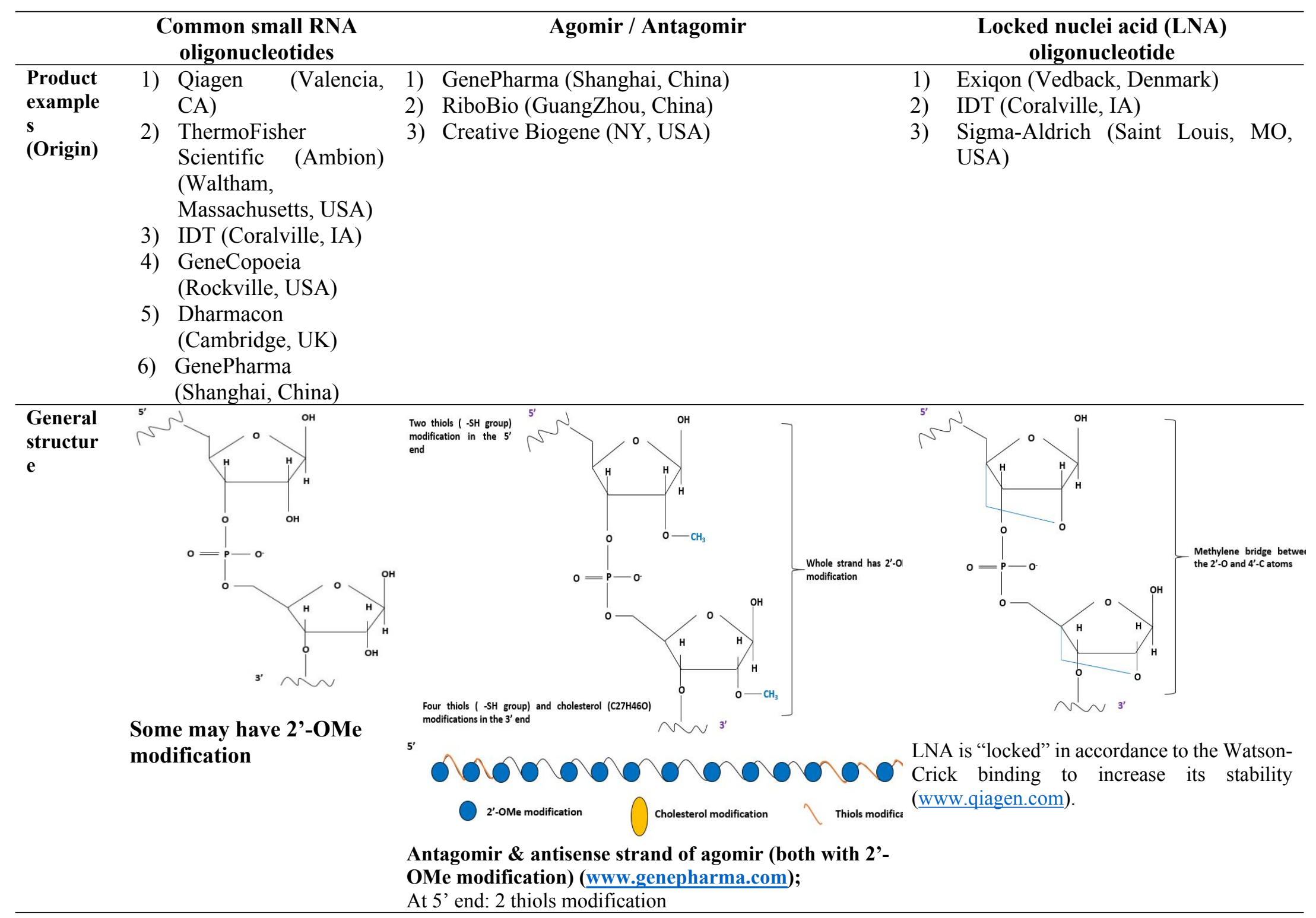


At 3' end: 4 thiols modification and cholesterol

modification 


\begin{tabular}{|c|c|c|c|}
\hline $\begin{array}{l}\text { Number of } \\
\text { strands }\end{array}$ & $\begin{array}{l}\text { May be single or double-stranded } \\
\text { (duplex) }\end{array}$ & $\begin{array}{l}\text { Agomir: Double-stranded } \\
\text { Antagomir: Single-stranded }\end{array}$ & $\begin{array}{l}\text { Mimic: Triple-stranded (One guide } \\
\text { strand and two passenger strands) } \\
\text { Antagonist: Single-stranded }\end{array}$ \\
\hline Strengths & $\begin{array}{l}\text { 1) Commonly available and } \\
\text { cheaper } \\
\text { 2) Easy to be introduced into host } \\
\text { cells }\end{array}$ & $\begin{array}{l}\text { 1) Stable structure and effective in action } \\
\text { 2) Higher affinity towards cell membrane, } \\
\text { 3) Longer interfering effect which may last } \\
\text { up to } 6 \text { weeks }\end{array}$ & $\begin{array}{l}\text { 1) Effective and stable structure } \\
\text { 2) May or may not require } \\
\text { transfection reagent }\end{array}$ \\
\hline $\begin{array}{l}\text { Efficiency } \\
\text { comparison }\end{array}$ & & Superior than normal mimics/inhibitors & $\begin{array}{l}\text { LNA oligonucleotides }>\text { common } \\
\text { oligonucleotides Mixture of } \\
\text { LNA+OMe oligonucleotides }> \\
\text { common oligonucleotides }\end{array}$ \\
\hline References & $\begin{array}{l}\text { (Cheng et al. 2005; Bell and } \\
\text { Micklefield 2009; Jensen et al. 2014; } \\
\text { Jin et al. 2015) }\end{array}$ & $\begin{array}{l}\text { (Krützfeldt et al. 2005; Chen et al. 2015; } \\
\text { Merhautova et al. 2016; Hu et al. 2017) }\end{array}$ & $\begin{array}{l}\text { Tolstrup et al. 2003; Chan et al. } \\
\text { 2005; Fabani and Gait 2008; } \\
\text { EXIQON RNA Functional Analysis } \\
\text { Handbook 2016; Qiagen miRCURY } \\
\text { LNA Mimics and Inhibitors and } \\
\text { Target Site Blockers Handbook 2017; } \\
\text { Piao et al. 2018) }\end{array}$ \\
\hline
\end{tabular}




\section{Table 2 (on next page)}

Comparison of the different methods for the assessment of transfection efficiency

Different approaches for assessing transfection efficiency 
1 Table 2: Comparison of the different methods for the assessment of transfection efficiency

\begin{tabular}{|c|c|c|c|c|c|}
\hline & $\begin{array}{l}\text { Fluorescence } \\
\text { Microscopy }\end{array}$ & $\begin{array}{c}\text { Real time } \\
\text { PCR (qPCR) }\end{array}$ & $\begin{array}{l}\text { Plasmid } \\
\text { reporting } \\
\text { system }\end{array}$ & $\begin{array}{c}\text { Flow } \\
\text { cytometry }\end{array}$ & $\begin{array}{l}\text { Others, eg: western } \\
\text { blot \& } \\
\text { Immunofluorescent } \\
\text { staining }\end{array}$ \\
\hline Descriptions & $\begin{array}{l}\text { Use of } \\
\text { fluorescently } \\
\text { tagged } \\
\text { molecules to } \\
\text { confirm } \\
\text { transfection has } \\
\text { taken place }\end{array}$ & $\begin{array}{l}\text { Directly } \\
\text { measures the } \\
\text { expression } \\
\text { level of nuclei } \\
\text { acids post- } \\
\text { transfection }\end{array}$ & $\begin{array}{l}\text { Indirectly } \\
\text { measures } \\
\text { transfection } \\
\text { efficiency via a } \\
\text { luminescence } \\
\text { measurement or } \\
\beta \text {-galactosidase } \\
\text { level }\end{array}$ & $\begin{array}{l}\text { Quantify the } \\
\text { number of } \\
\text { fluorescently } \\
\text { labelled } \\
\text { transfected } \\
\text { cells }\end{array}$ & $\begin{array}{l}\text { Indirectly monitor the } \\
\text { transfection efficiency } \\
\text { via detection or } \\
\text { quantification of } \\
\text { downstream targeted } \\
\text { protein expression }\end{array}$ \\
\hline $\begin{array}{l}\text { Quantitative } \\
\text { or qualitative } \\
\text { findings }\end{array}$ & $\begin{array}{lr}\text { Qualitative } & \text { or } \\
\text { semi- } & \text { and } \\
\text { quantitative } & \end{array}$ & Quantitative & $\begin{array}{l}\text { Quantitative } \\
\text { using } \\
\text { luminescence } \\
\text { reporting system }\end{array}$ & Quantitative & $\begin{array}{c}\text { Semi-quantitative } \\
\text { (western blot); } \\
\text { Qualitative/ Semi- } \\
\text { quantitative } \\
\text { (Fluorescent } \\
\text { microscopy after } \\
\text { immunostaining); } \\
\text { Quantitative (Flow } \\
\text { cytometry after } \\
\text { immunostaining) }\end{array}$ \\
\hline Advantages & Easy and fast & $\begin{array}{l}\text { Allows } \\
\text { quantification } \\
\text { of the } \\
\text { transfection } \\
\text { efficiency }\end{array}$ & $\begin{array}{l}\text { Allows } \\
\text { quantification of } \\
\text { the transfection } \\
\text { efficiency }\end{array}$ & $\begin{array}{l}\text { Allows } \\
\text { quantification } \\
\text { of the } \\
\text { transfection } \\
\text { efficiency }\end{array}$ & $\begin{array}{l}\text { Allows simultaneous } \\
\text { assessment of the } \\
\text { regulation of } \\
\text { downstream protein } \\
\text { targets }\end{array}$ \\
\hline Disadvantages & $\begin{array}{l}\text { Inability to } \\
\text { distinguish } \\
\text { signals } \\
\text { originating from } \\
\text { interior vs } \\
\text { exterior of cells }\end{array}$ & $\begin{array}{l}\text { Expensive and } \\
\text { laborious } \\
\text { especially in } \\
\text { transient } \\
\text { transfection } \\
\text { where regular } \\
\text { monitoring of } \\
\text { the transfection } \\
\text { efficiency is } \\
\text { needed }\end{array}$ & $\begin{array}{l}\text { Reporting } \\
\text { system within } \\
\text { plasmids not } \\
\text { offered by all } \\
\text { manufacturers. }\end{array}$ & $\begin{array}{l}\text { Expensive, } \\
\text { and laborious }\end{array}$ & $\begin{array}{l}\text { Expensive, laborious } \\
\text { and time-taking; false } \\
\text { negative results may be } \\
\text { obtained due to } \\
\text { inappropriate sampling } \\
\text { time; non-specific } \\
\text { protein binding }\end{array}$ \\
\hline References & $\begin{array}{l}\text { (Marjanovič et } \\
\text { al. 2014; } \\
\text { Mastropietro et } \\
\text { al. 2015; Peng et } \\
\text { al. 2017) }\end{array}$ & $\begin{array}{l}\text { (Godbey et al. } \\
\text { 2008; Jiwaji et } \\
\text { al. 2010; } \\
\text { Thomson et al. } \\
\text { 2013; Werling } \\
\text { et al. 2015) }\end{array}$ & $\begin{array}{l}\text { (Nasim and } \\
\text { Trembath 2005; } \\
\text { Jiwaji et al. } \\
\text { 2010; Horibe et } \\
\text { al. 2014; } \\
\text { Marjanovič et } \\
\text { al. 2014; Yun } \\
\text { and DasGupta } \\
\text { 2014) }\end{array}$ & $\begin{array}{l}\text { (Ho et al. } \\
\text { 2006; } \\
\text { Marjanovič et } \\
\text { al. 2014; } \\
\text { Homann et al. } \\
\text { 2017) }\end{array}$ & $\begin{array}{l}\text { (Weilin et al. 2004; } \\
\text { Buchwalow et al. 2011; } \\
\text { Granieri et al. 2012; } \\
\text { Liang et al. 2013; Bass } \\
\text { et al. 2017; Peng et al. } \\
\text { 2017; Shi et al. 2018) }\end{array}$ \\
\hline
\end{tabular}




\section{Table 3(on next page)}

Table 3: Factors influencing the efficiencies of viral and physical/mechanical transfection methods

Factors influencing the efficiencies of viral and physical/mechanical transfection methods 
Table 3: Factors influencing the efficiencies of different transfection methods

\begin{tabular}{|c|c|c|c|c|c|c|}
\hline & \multirow[b]{2}{*}{ Virus transduction } & \multicolumn{5}{|c|}{ Physical / mechanical transfection methods } \\
\hline & & Electroporation & Laser beam & $\begin{array}{c}\text { Nucleic acid } \\
\text { injection }\end{array}$ & $\begin{array}{c}\text { Ultrasound- } \\
\text { assisted }\end{array}$ & $\begin{array}{l}\text { Magnet- } \\
\text { assisted }\end{array}$ \\
\hline $\begin{array}{l}\text { Factors } \\
\text { affecting } \\
\text { transfection } \\
\text { efficiencies }\end{array}$ & $\begin{array}{l}\text { 1) Virus type/generation } \\
\text { 2) Cell type } \\
\text { 3) Promoter present in } \\
\text { viral vector } \\
\text { 4) Presence of other } \\
\text { substances during } \\
\text { transduction }\end{array}$ & $\begin{array}{l}\text { 1) Electroporation } \\
\text { condition (duration and } \\
\text { voltage used) } \\
\text { 2) Number of electric } \\
\text { pulses } \\
\text { 3) Cell type } \\
\text { 4) Electroporation } \\
\text { buffer composition } \\
\text { 5) Size and } \\
\text { concentration of } \\
\text { nucleic acids }\end{array}$ & $\begin{array}{l}\text { 1) Laser condition } \\
\text { (power density and } \\
\text { duration) } \\
\text { 2) Number of laser } \\
\text { pulses } \\
\text { 3) Cell type }\end{array}$ & $\begin{array}{l}\text { 1) Number of } \\
\text { injection repeat } \\
\text { 2) Amount of } \\
\text { injected nucleic } \\
\text { acids } \\
\text { 3) Size, shape and } \\
\text { coating of needle } \\
\text { 4) Cell type }\end{array}$ & $\begin{array}{l}\text { 1) Ultrasound } \\
\text { exposure condition } \\
\text { 2) Number of } \\
\text { pulses } \\
\text { 3) Cell culture } \\
\text { condition } \\
\text { 3) Cell type } \\
\text { 4) Amount of } \\
\text { nucleic acids used }\end{array}$ & $\begin{array}{l}\text { 1) } \\
\text { Magnetic } \\
\text { condition } \\
\text { (oscillating } \\
\text { or static } \\
\text { conditions) } \\
\text { 2) } \\
\text { Modificati } \\
\text { on of the } \\
\text { magnetic } \\
\text { nanoparticl } \\
\text { es } \\
\text { 3) Number } \\
\text { of pulses } \\
\text { 4) Cell } \\
\text { type }\end{array}$ \\
\hline References & $\begin{array}{l}\text { (Haas et al. 2000; Ikeda } \\
\text { et al. 2002; Denning et } \\
\text { al. 2013) }\end{array}$ & $\begin{array}{l}\text { (Potter and Heller } \\
\text { 2003; Molnar et al. } \\
\text { 2004; Yao et al. 2009; } \\
\text { Hornstein et al. 2016; } \\
\text { Chopra et al. 2020; } \\
\text { Sherba et al. 2020) }\end{array}$ & $\begin{array}{l}\text { (Stevenson et al. } \\
\text { 2006; Terakawa et al. } \\
\text { 2006; Tsen et al. } \\
\text { 2009) }\end{array}$ & $\begin{array}{l}\text { (Wells et al. 1998; } \\
\text { Dahlhoff et al. 2012; } \\
\text { Mellott et al. 2013; } \\
\text { Chow et al. 2016) }\end{array}$ & $\begin{array}{l}\text { (Jr. et al. 2006; } \\
\text { Kinoshita and } \\
\text { Hynynen } 2007 ; \\
\text { Zhou et al. 2012) }\end{array}$ & $\begin{array}{l}\text { (Mykhayly } \\
\text { k et al. } \\
\text { 2007; } \\
\text { Fouriki et } \\
\text { al. } 2010 \text {; } \\
\text { Kardos and }\end{array}$ \\
\hline
\end{tabular}


Rabussay

2012;

Wang et al.

2014) 


\section{Figure 1}

Figure 1: The workflow of literature selection using PRISMA flow strategy.

Keywords used during the literature search included "transfection", "co-transfection", "chemicals", "reagents", "DNA", "siRNA", "shRNA", "miRNA", "plasmid", "oligonucleotides", "efficiency", "safety", "cytotoxicity", and "controls". Inclusion criteria of the literature selection comprised of English written articles or sources which were reported in the past 30 years since 1990 and articles which reported the description or comparison betweendifferent transfectionprotocols, types of transfected nucleic acids,transfection controls, methods to assess transfection efficiencies and transfectionreagentsin terms of theirstrengths, effectiveness,safety leveland/or limitations.About 150 written sources were used in the qualitative analysis of this technical review. 


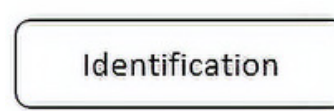

Screening

Eligibility

Included

Records identified
through PubMed
database searching
$(\mathrm{n}=1500)$
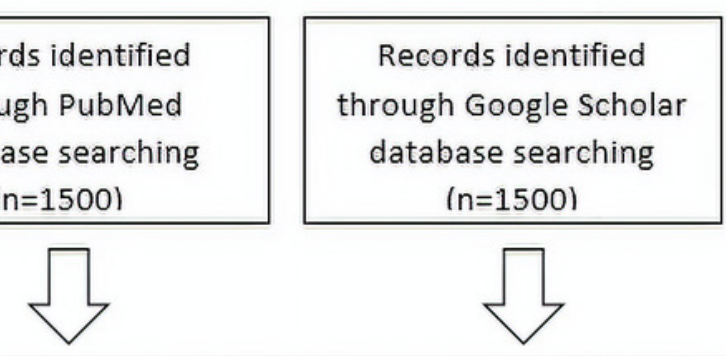

Records after removal of duplicate articles or sources $(n=500)$

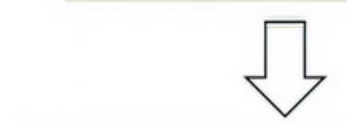

Records screened $(n=500)$

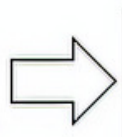

Records excluded for not fulfilling the keywords, unsuitable titles or articles which are not written in English $(n=250)$

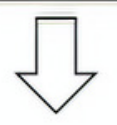

Full-text articles / sources assessed for eligibility $(n=250)$

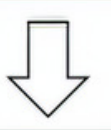

Full-text articles / sources excluded for the inaccessible full texts, conference proceedings and letters to editor $(n=100)$
Studies / sources included in qualitative synthesis $(n=150)$ 
Figure 2

Figure 2: Different transfection protocols that can be divided into viral-based, non-viral based or combination of both (hybrid).

Different transfection protocols that can be divided into viral-based, non-viral based or combination of both (hybrid).

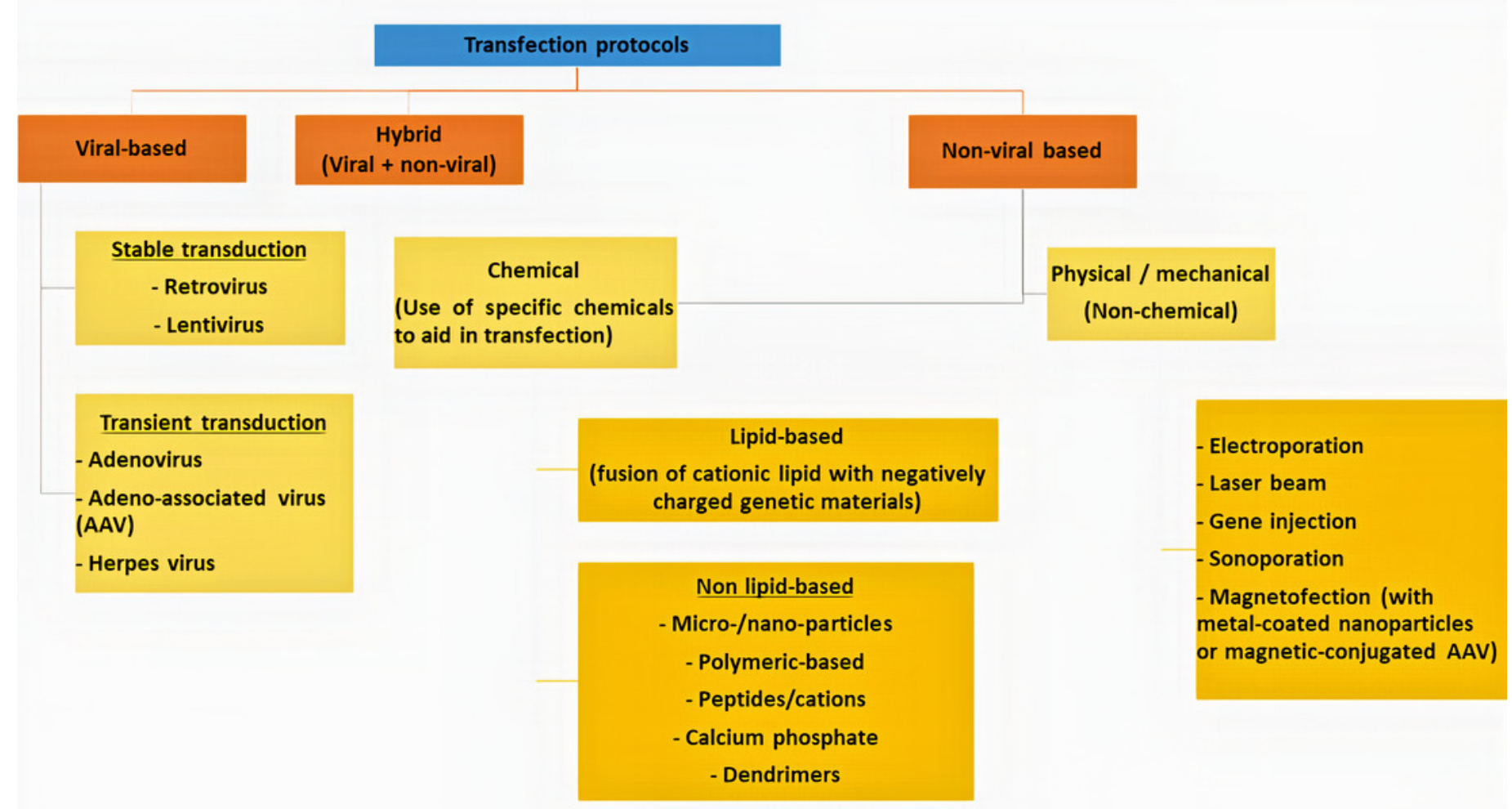




\section{Figure 3}

Figure 3: Summary of the commonly used chemical transfection reagents.

Transfection reagents can be generally divided into liposomal or high-lipid based and nonliposomal based reagents. Non-liposomal reagents can be mixed protein-lipid reagents, nonliposomal lipids or non-protein non-lipid reagents like dendrimer. The details of the Invitrogen and ThermoFisher Scientific products can be found at: https://www.thermofisher.com/my/en/home.html . Information on the Qiagen related transfection products can be found at: https://www.qiagen.com/us/ . Information on the Promega related reagents can be found at: https://worldwide.promega.com/. For Polyplus related transfection reagents, the information can be retrieved at:

https://www.polyplus-transfection.com/ . For Sigma-Aldrich or Merck or Roche related reagents, the information can be found at: https://www.sigmaaldrich.com/united-states.html . Information on the Thomas Scientific related chemicals can be retrieved at:

https://www.thomassci.com/. Details on the Mirus Bio products can be referred at: https://www.mirusbio.com/ . For GeneCopoeia products, further information can be found at: https://www.genecopoeia.com/ . Information on ClonTech products can be found at: https://www.takarabio.com/. Details on System Biosciences chemicals can be found at: http://www.excellbio.com/ . Information on the products by Strategene can be found at: https://www.agilent.com/. Details of the Fermentas International Inc. can be found at: http://fermentas.lookchem.com/. 


\section{Transfection reagents}

\section{Pure / high-lipid based}

1) Oligofectamine, Lipofectamine LTX, Plus, 2000, 3000 and RNAiMAX and Lipofectin by Invitrogen (Rockford, II, USA)

2) siPORT Amine by ThermoFisher Scientific (Waltham, Massachusetts, USA)

3) DharmaFECT 1, 2, 3 and 4 by Dharmacon (Cambridge, UK)

4) DOTAP by Roche (Mannheim, Germany)

5) HiPerfect by Qiagen (Valencia, CA)

6) Endofectin@Max by GeneCopoeia (Rockville, USA)

7) Nanofectamine by PAA (GE Healthcare, Illinois, USA)

8) Escort IV Liposome by Sigma-Aldrich (Saint Louis, MO, USA)

\section{Mixed lipid \& non-lipid based}

1) Arrest-In by Dharmacon (Cambridge, UK)

2) Turbofect by Thermo Scientific (Huntsville, $A L$ )

3) Effectene, Attractene, PolyFect and Superfect by Qiagen (Valencia, CA)

4) ExpressFect by Thomas Scientific (Metuchen, NJ)

5) ExGen 500 by Fermentas International Inc. (Burlington, Ontario, Canada)

6) GeneJammer by Stratagene (La Jolla, CA, USA)

7) Viafect, FuGENE 6 and FuGENE HD by Promega (Madison, WI, USA)

8) jetPEI, JetPrime and INTERFERin by Polyplus transfection (New York, NY, USA)

9) NanoFectin by System Biosciences (Shanghai, China)

10) Escort IV and N-TER by Sigma-Aldrich (Saint Louis, MO, USA)

11) TransIT-TKO, TransIT- $X 2$, TransIT-2020, TransITSiQuest and TransIT-LT1 by Mirus Bio LLC (Madison, WI)

12) X-tremeGENE 9, X-tremeGENE 360 and X-tremeGENE HD by Roche (Mannheim, Germany)

13) Xfect by ClonTech (Mountain View, CA, USA) 
Figure 4

Figure 4: Applications of co-transfection in biotechnology and life sciences research.

(A) Multiple plasmids co-transfection is useful in generating a hybrid vector and is for protein-protein interaction studies. (B) Multiple small RNAs co-transfection is popular in RNA interference and functional assay study to evaluate the regulatory effects of the small RNA on the expression of the downstream target. (C) Co-transfecting a small RNA molecule and a plasmid DNA that carries a reporter system can be used to assess small RNA transfection efficiency or to determine the regulatory effects of the small RNA on a specific gene.

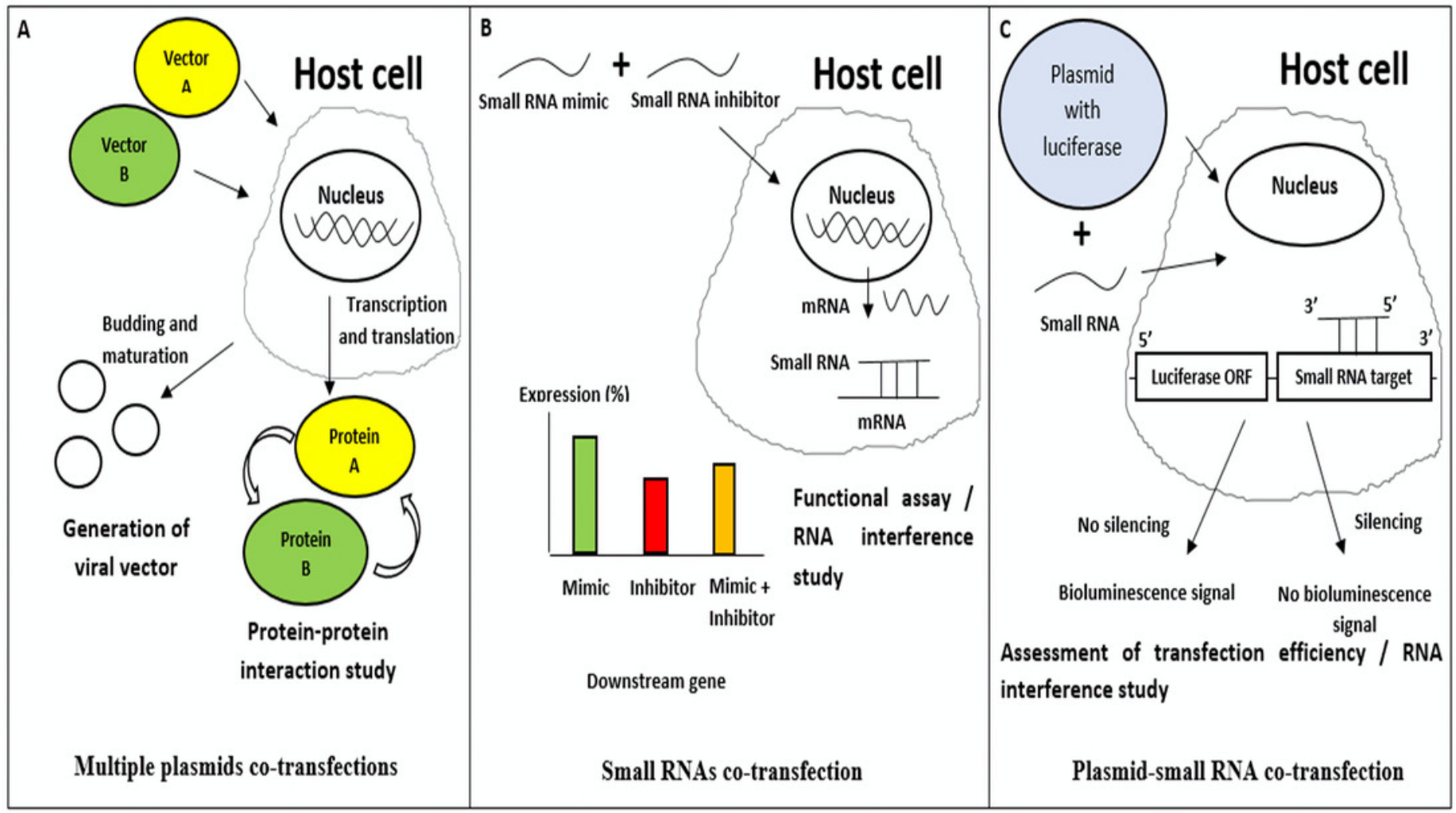

